\title{
İbn Sînâ'ya Göre Allah Cüz’̂̂leri Bilir; Fakat Nasıl?
}

\section{God Knows Particulars According to Avicenna; But How?}

\section{Hafzullah Genç}

Arș. Gör. Dr., Hitit Üniversitesi, İlahiyat Fakültesi, Kelam Anabilim Dalı

Research Assist. PhD., Hitit University, Faculty of Theology, Department of Kalam

Corum/ Turkey

hafzullahgenc@hitit.edu.tr | https://orcid.org/0000-0003-0486-5581

Article Type / Makale Tipi

Research Article / Araștırma Makalesi

DOI: $10.33420 /$ marife. 909923
Article Information / Makale Bilgisi

Received / Geliş Tarihi: 20.02.2021

Accepted / Kabul Tarihi: 08.06.2021

Published / Yayın Tarihi: 30.06.2021

Cite as / Atıf: Genç, Hafzullah. “íbn Sînâ’ya Göre Allah Cüz'îleri Bilir; Fakat Nasıl?”. Marife 21/1 (2021), 605-627. https://doi.org/10.33420/marife.909923

Plagiarism / Intihal: This article has been reviewed by at least two referees and scanned via a plagiarism software. / Bu makale, en az iki hakem tarafindan incelendi ve intihal içermediği teyit edildi.

\section{(c) (1) $(9)$}

Copyright / Telif Hakkı: "This article is an open access article distributed under the terms and conditions of the Creative Commons Attribution-NonCommercial-NoDerivatives 4.0 (CC BY-NC-ND 4.0) International License." / "Bu makale Creative Commons Alınt-GayriTicari-Türetilemez 4.0 (CC BY-NCND 4.0) Uluslararası Lisansı altında lisanslanmıştır."

e-ISSN: 2630-5550

www.marife.org 


\section{İbn Sînâ'ya Göre Allah Cüz'îleri Bilir; Fakat Nasıl?}

Özet

İbn Sînâ'nın kurduğu felsefi sistem içerisinde Allah'ın cüz'îleri nasıl bildiğine dair görüşü bu mesele hakkında günümüze kadar gelen tartışmaların sebebidir. İbn Sînâ görüşünü açıklarken önce O'nun cüz'̂̂leri bilmediğini daha sonra ise bildiğini söylemiştir. Bu durum İbn Sînấyı açık bir çelişkiye düşmüş gibi göstermektedir. Fakat burada bir ayrıntı vardır: İbn Sînâ'nın Allah'ın bilmediğini söylediği cüz'îler değişken cüz'îlerdir. Çünkü ona göre değişken cüz'̂̂leri bilmenin yolu onları duyularla algılamaktadır. Allah duyulara sahip olmadı̆̆ı için değişken cüzîleri bilemez. Fakat yine İbn Sînâ'ya göre hiçbir şey Allah'ın bilgisinin dışındakalamaz. Buna göre Allah'ın değișken cüzîleri de bilmesi gerekir. Bu sebeple İbn Sînâ Allah'ın cüz'̂̂leri nasıl bildiğine dair bir açılama yapmalıdır. $O$ da bu açıklamayı özetle şöyle yapmıştır: "Allah kendisini bilir. Allah her şeyin varlık sebebidir. Sebebi bilen sonucu da bilir. Allah her şeyin sebebi olduğuna ve Allah kendisini bildiğine göre mevcudatın hepsini bilir. Böylece $O$, her șeyi sebebiyle, küllî olarak bilir. Sebepler değişken değildir. Bu nedenle de değișken cüz'̂̂leri sebepleriyle bilmesi O'nun bilgisinde değişime yol açmaz."

Gazzâlî Tehâfütü'l-felâsife isimli bir eser yazarakfilozofların ve İbn Sînâ'nın görüşlerini eleștirmiştir. Allah'ın cüz'îleri bilmesi meselesinde sarf ettiği sözlerin Allah'ın cüz'̂̂leri bilmediği sonucuna vardığını söyleyerek İbn Sînâ'yı küfürle itham etmiștir. Çünkü Gazzâlî̀ye göre birisinin Allah değișken cüz'̂̂leri bilmez ya da sebepleriyle bilir demesi en basit anlamda O'nun bazı șeyleri bilmediğinisöylemektir. Allah duyulara konu olan değișken cüz'îleri bilmediği takdirde mesela Zeyd'in küfürden sonra iman ettiğini ya da Hz. Muhammed'in peygamberlik ilan ettiğini bilmiyor olmaktadır. Bu ithamdan sonra hangi düşünürün haklı olduğuna dair ortaya çıkan tartışmalar neticesinde İbn Sînâ'nın haklı olduğunu söyleyenler onun sözlerine izah getirmeye çalışmaktadırlar. Hem klasik hem de modern dönemde yapılan izahlar Gazzâlî̀yi haklı bulanlar tarafından tatmin edici olmadığı gerekçesiyle tenkit edilmeye devam edilmektedir.Klasik dönemde Kutbuddin Râzî tarafından yapılan ve bize göre gözden kaçan bir izah ise bize İbn Sînâ'nın tenkitlerden nasıl kurtulacağının işaretini vermektedir.

Kutbuddîn Râzî̀ye göre İbn Sînâ Allah'ın her șeyi ezelde kendi vakitlerinde bildiğini söylemektedir. İbn Sînâ'nın bu düşüncede olduğunukendi eserlerinden de teyit etmek mümkündür. Buna göre İbn Sînâ nezdinde Allahcüz'̂̂ler de dâhil vakitleriyle beraber her şeyin bilgisine daha önceden sahiptir ve vakti gelen her şey ortaya çıkmaktadır. Buradan hareketle İbn Sînâ'nın cebrî düşünceye yaklaştığı kanısına varılabilir ki eserlerinde cebrî düşünceye rastlamak zor değildir. Insanların ihtiyarıyla ilgili sözleri onun cebrî düşünceden çok uzak olmadığını göstermektedir. Nitekim İbn Sînâya ait olan ve Ta'lîkât'ta yer alan "İnsan muhtar görünümlü muztardır" ifadesi ve sonrasında söyledikleri onun insanların fiillerinde özgür olmadığını düşündüğünü göstermektedir. İbn Sînâ insanların fiillerinin zorunlu olarak bir sebebe bağlı olduğunu düşünmektedir. Bu sebeplerin de zincir halinde Allah'a kadar uzandığını, O'nun ilk sebep olduğunu ve O'nun indinde her şeyin zorunlu olduğunu söylemektedir. Hal böyle olunca da bu sebeplerle ortaya çıkan her şey zorunlu olmaktaktadır. İbn Sînâ'nın bu konudaki fikirleri Cebriye ve Ehl-i sünnet arasında kalmaktadır. Cüz'̂̂lerin ortaya çıkışı konusunda Cebriyeye paralel giden İbn Sînâ, Allah'ın bilgisi konusunda Ehl-i sünnete yaklaşmıştır. Ehl-i sünnete göre Allah her şeyi ezelde, tek bir ilimle, zatında ve ilminde değiş̧iklik olmadan bilmektedir. İbn Sînâ da benzer ifadelerle Allah'ın her șeyi ezelde, kendi vakitlerinde, küllî olarak, bir defada, ilminde değişim olmadan bilmektedir. Fakat onun yaptığı sebepleriyle bilmek açıklaması meseleyi başka yerlere taşımakta, Allah'a çokluk izafe etmemek adına yaptı̆̆ı bu açıklama farklı sonuçlar doğurmaktadır.

Bu çalışmada Kutbuddin Râzînin İbn Sînâ'nın görüşünü açıklarken kullandığı bazı ifadelerden yola çıkılarak İbn Sînâ'nın kendi eserlerinden onun Allah'ın varlığa dair bilgisiyle ilgili görüşü yeniden bir okuma ve değerlendirmeye tabi tutulmuştur. Böylece onun Allah'ın değişken cüz'̂̂leri hatta her şeyi nasıl bildiğine dair görüşünün aslında farklı olduğu sonucuna ulaşılmıştır. Ulaşılan bu sonuç ibn Sînâ'nın asıl görüşünü gizlemek adına farklı şeyler söylediği iddiasını doğrular gibi görünmekle beraber onu Allah'ın cüz'̂̂leri bilmediği görüşünü savunduğu ithamından da kurtarmaktadır.

Anahtar Kelimeler: Kelam, Sıfatlar, İlim, Cüz'̂̂lerin Bilinmesi, İbn Sînâ.

\section{God Knows Particulars According to Avicenna; But How?}

\section{Summary}

Within his philosophical system, Avicenna's opinion on "how God knows the particulars" is a significant ongoing debate that continues today. While Avicenna was explaining his opinion, he first claimed that God does not know the particulars, and then later on he suggested the opposite. This 
situation indicates that Avicenna might have been in a contradiction. However, there is a small nuance here: Avicenna suggested that God doesn't know mutaghayyirat which refers to particulars in motion. According to Avicenna mutaghayyirat is merely known with senses, but because God doesn't have senses in the way we do, He doesn't know mutaghayyirat. But, again in Avicenna's philosophy, nothing is beyond God's knowledge. So here, the question of "how God knows mutaghayyirat" begs for an answer. Therefore, Avicenna made the necessary statement on this issue briefly as follows: "God knows himself. God is the reason for the existence of everything. Who knows the reason also knows the result. God knows everything since He is the reason for everything, and He knows himself. So, He universally knows everything with their reasons. Reasons are not mutaghayyir. Consequently, knowing mutaghayyirat through reasons does not cause His knowledge to change."

Ghazali criticizes philosophers and Avicenna's views in his book "Tahafut al-falasifa". In this book, he accuses Avicenna of heresy due to his opinions on God's knowledge of particulars. Because according to Ghazali, when someone says God does not know particulars or He knows particulars because of their reasons, he ultimately means God doesn't know some things. If God doesn't know mutaghayyirat which is subjected to senses, He did not know that, for example, Zeyd believed after heresy or Prophet Mohammed(pbuh) declared prophethood. After this accusation, a discussion arose about which thought was accurate. Those who said that Avicenna was right wanted to explain his views on God's knowledge. In both the classical and modern periods, explanations made by his supporters were criticized by Ghazali's supporters. In the classical period, the explanation made by Kutbuddin Razi, which according to us was under-appreciated, offers a way for Avicenna to escape criticism on this issue.

According to Kutbuddin Razi, Avicenna claims that God eternally knows everything and when the events will take place. According to this view, God has the knowledge of everything, their time of realization, including particulars, and thus the existence of everything and their time. Drawing from this idea, one might say that Avicenna was close to the Jabriyyah sect on the issue of destiny. And this claim could be backed up by pieces of evidence from his books. His words on the actions of humans have traces of Jabriyyah's way of thinking. The phrase "Man is mukhtar-looking mudztar" belongs to Avicenna and what he said afterward shows that he thinks the man is not free in his actions. Avicenna thinks that man's actions necessarily depend on a reason. Also, he says this reason goes all the way up to God in the chain, He is the first reason, and everything is necessary because of/for Him. In this case, everything that exists because of a reason is necessary. Avicenna's ideas on this issue can be seen as in between Jabriyyah and Ahl al-sunnah. Avicenna who draws closer to Jabriyyah on the existence of particulars, stands closer to Ahl-al sunnah on God's Knowledge. In the thought of Ahl al-Sunnah, God eternally knows everything, knows their time, and knows without taghayyur/change in His person and knowledge. Avicenna also thinks similarly on the issue of God's knowledge. He believes that God eternally knows everything, knows their time without taghayyur/change in His person and knowledge. However, Avicenna's explanation about knowing things due to their reasons moves the issue elsewhere. This explanation he came up with to avoid attributing plurality to God bears other consequences.

In this article, while we rely on Kutbuddin Razi's explanation about Avicenna's view on God's knowledge and drawing from some of his statements about Avicenna's views, his idea on God's knowledge of things has been reevaluated. As a result, we have concluded that his ideas on how God knows particulars and furthermore how he knows everything is different than what people believe. This result, though seem to confirm the allegations that he said different things to hide his actual thoughts on the issue, also saves him from the allegations that claim he believed God does not know the particulars.

Keywords: Theology, Attributes, Knowledge, Knowledge of Particulars, Avicenna.

\section{Giriș}

Gazzâlî,Tehâfütü'l-felâsife'nin on üçüncü meselesine "Filozofların sözlerinden münezzeh olan Allah'ın, oluyor, oldu ve olacak şeklinde zamana bölünen cüz’̂̂leri bilmediğine dair onların (felsefecilerin)iddialarının iptali hakkında- 
dır"1başlığını vermiştir. Bunun sebebi, mezkûr başlık altında ele aldığı meselede, genelde filozofların özelde ise İbn Sînâ'nınAllah'ın bilgisine dair görüşlerini eleştirmek ve aksini ispat etmektir. Gazzâlî bunu yaparken aynı zamanda filozofların bu meseledeki fikirlerinin kendilerini küfre götürdüğünü söylemiş, onları küfürle itham etmiştir. Gazzâlî ile başlayan tartışmalar, sonraki dönemde onun doğrudan İbn Sînâ'yı hedef göstermesi ve tekfir etmesi sebebiyle İbn Sînâ üzerinden devam etmiş ve yazılan eserler Gazzâlî'nin İbn Sînâ'yı ithamını temel alarak oluşturulmuştur. Çünkü Allah'ın cüz'îleri bilmediğine ilişkin bu itham basitçe geçiștirilecek nitelikte değildir. Her ne kadar İbn Sînâ böyle söylemese de malumdur; Allah'ın bilmediği bir şey olduğunu söylemek itikat açısından büyük problem oluşturmaktadır. Zannediyoruz ki Gazzâlî de bu çerçeveden bakarak Allah'ın bilmediği bazı şeyler olduğunun söylenmesine tepki göstermiş ve İbn Sînâ'yı küfürle suçlamıştır.

Tartışma başladıktan sonra âlimler, İbn Sînâ'yı savunanlar ve Gazzâlî́yi haklı bulanlar olarak yavaş yavaş saflarını belirlemişlerdir. Gazzâlî̀yi haklı bulanlar Ortaçağ'da hem Müslüman hem de Hristiyan dünyanın kalabalık kesimini oluşturmaktır. ${ }^{2}$ Çalışmamıza dâhil olmadığı için Hristiyanları bir kenara bırakırsak, bu Müslüman grubun İslam'ı ve mensuplarını “felsefenin saçmalıkları" ve "filozofların hezeyanlarından" koruma güdüsüyle hareket ettiği söylenebilir. Bu sebeple Gazzâlînnin tekfir dili ilgi görmüş vetartışmanın yaygınlaşması ve devamlılığının da sebebi olmuştur. Ancak tekfir tavrı daha sonra devam ettirilmemiştir. Zira İbn Rüşd'ün de Faslü'l-makal'de belirttiği üzere ${ }^{3}$, Gazzâlî Faysalü't-tefrika'da isim vermeden sadece tavır olarak İbn Sînâ'nın bu mesele hakkındaki fikirlerinin küfür için yeter sebep olmadığını söylemiştir. ${ }^{4}$ Öyle de olsa Gazzâlî’nin küfür konusunda geri adım atması tartışmayı frenlememiştir. Çünkü tekfir edilmeye mahal olmasa bile halen ortada duran büyük bir sorun vardır: İbn Sînâ Allah Teâlâ'nın bazı şeyleri bilmediğini söylemiş midir söylememiş midir? Gazzâlî ve taraftarlarına göre cevap açıktır: Söylemiştir. İbn Sînâ taraftarlarına göre ise böyle bir şey söylemesi mümkün değildir ki zaten İbn Sînâ'nın Allah'ın her şeyi bildiğine dair açık beyanı vardır. Buna rağmen Gazzâlî ve taraftarları İbn Sînâ'ya Allah'ın cüz'îleri bilmediği görüşünü nasıl atfetmişlerdir? Bu sorunun cevabını bulmak için öncelikle İbn Sînâ'nın mesele hakkındaki sözlerini incelemek gerekecektir.

İbn Sînâ cüz'î varlıkların akılla bilinemeyeceğini söyledikten sonra Allah Teâlâ'nın cüz'î varlıkları bildiğini söylemesi ilk bakışta bir çelişki oluşturmaktadır. Çünküo, Allah'ın sırf akıl olduğunu söylemekte, O'nun bilgisinin sadece akletmekten ibaret olduğunu belirtmektedir. Bununla birlikte o, Allah'ın sadece duyularla idrak edilebilen cüz'î varlıkları da küllî olarak bildiğini iddia etmektedir. ${ }^{5}$

${ }^{1}$ Ebû Hâmid Muhammed b. Muhammed b. Muhammed b. Ahmed Gazzâlî, Tehâfütü'l-felâsife, thk. Ahmed Şemseddin (Beyrut: Dâru'l-kütübi'l-ilmiyye, 2010), 142.

2 Rahim Acar, "Yaratan Bilmezse Kim Bilir? İbn Sînâ'ya Göre Allah'ın Cüz’̂̂leri Bilmesi”, Íslam Araştırmaları Dergisi 13 (2005), 2.

${ }^{3}$ Muhammed b. Ahmed b. Muhammed el-Kurtubî İbn Rüşd, Felsefe-Din İlişkileri, çev. Süleyman Uludağ (İstanbul: Dergah Yayınları, 2016), 91.

${ }^{4}$ Ebû Hamîd Muhammed b. Muhammed Gazzâlî, Faysalü't-tefrika, çev. Hikmet Akpur (İstanbul: İlk Harf Yayınevi, 2015), $81 \mathrm{vd}$.

${ }^{5}$ Ebû Alî el-Hüseyn b. Abdillâh b. Alî İbn Sînâ, et-Ta'lîkât (Kum: Mektebetü'l-ilâmi'l-İslâmî, 1404), 14. 
Gazzâlî, İbn Sînâ'nın görüşünü temel alarak Allah'ın cüz'îleri bilmesi meselesini,Tehâfütü'l-felâsife isimli eserinde, filozofları eleştirdiği yirmi konu arasına dâhil etmiștir. Bunun yanında aynı mesele yirmi konu arasında Gazzâlî̀ye göre filozofların küfre girdiği üç meseleden biridir. Bizce tartışmanın büyük boyutlara ulaşmasının nedeni deGazzâlînnin filozofları küfürle ithamıdır. Nitekim tartışma büyük boyutlara ulaşmış hatta bu tartışma Tehâfüt'te yer alan diğer on dokuz meseleyle birlikte bir geleneğe dönüşmüştür.

Allah'ın cüz'îlere dair bilgisi hakkında İbn Sînâ'nın görüșü üzerindeki tartışma iki koldan yürütülmektedir. Birincisi Gazzâlî̀nin Tehâfüt'ü ile başlayan, İbn Rüşd tarafından devam ettirilen ve Osmanlı döneminde bir geleneğe dönüşen tehâfüt yazımıdır. Gazzâlî filozofların, fikirlerini herhangi bir delil olmaksızın zanla hareket ederek ortaya attıklarını iddia etmiş ve bu iddiasını kanıtlamak için Tehâfütü'l-felâsife'yi yazmıştır. Hatalı olduklarını düşündügü yirmi meselede filozofları eleştirmiştir. Özellikle âlemin ezeliliği, Allah'ın cüz'îleri bilmemesi ve cismânî hașrin yokluğu filozofların,Tehâfüt'te eleștiri oklarının en büyüklerine hedef oldukları görüşleridir. Gâzzâlî filozofları âlemin ezeli olduğunu, Allah'ın cüz'îleri bilmediğini ve haşrin cismânî değil ruhânî olduğunu söyledikleri için tekfir etmiştir. Gazzâlî gibi ünlü ve saygın bir âlimin, Fârâbî ve İbn Sînâ gibi meşhur âlimleri tekfir etmesi Müslümanlar nezdinde büyük bir yankı uyandırmıştır. Buna rağmen Gazzâlîye karşı ilk cevap İbn Rüşd'den neredeyse bir asır sonra gelmiştir. İbn Rüşd, Gazzâlî̀ye reddiye olarak yazdığı Tehâfütü't-Tehâfüt isimli eserinde, bazı konularda Fârâbî ve İbn Sînâ'yı eleştirse de genel anlamda onları Gazzâlî̀ye karşı savunmuştur

İbn Rüşd'ün attığı bu adım haklı olanı belirleme çabası olarak algılanmış ve bu çabaya dâhil olmak isteyenler yine aynı isimle yani Tehâfüt ismiyle eser kaleme almışlardır. Bunlardan meşhur olan ve günümüze ulaşanları Hocazâde, Ali Tûsî, Kemalpaşazâde, Karabâĝ̂, Üsküdârî ve Musa Kazım Efendi'ye aittir. Bunların dışında literatürde beş farklı tehâfüt daha zikredilmiştir. Ancak kitaplar hakkında bilgi yoktur. ${ }^{6} \mathrm{Bu}$ eserlerde yer alan problemlerden biri Allah'ın cüz'îleri bildiğine dair İbn Sînâ'nın delilinin O'nun cüz'îleri bildiğini ispat edememesi dolayısıyla da İbn Sînâ'ya göre Allah'ın cüz'îleri bilmiyor olmasıdır. Gazzâlî, İbn Rüşd ve Ali Tûsî’nin tehâfütlerinde on üçüncü, Hocazâde ve Kemalpaşazâde'nin tehâfütlerinde ise on beșinci bölüm bu meseleye ayrılmıștır. Bu farklılığın nedeni Hocazâde'nin on üçüncü meseleyi üç bölüme ayırıp hepsini ayrı bölümler altında incelemesidir. Kemalpşazâde de onu takip etmiştir. ${ }^{7}$ Muhaşşîlerden Karabâği ise eserini on ikinci bölümde tamamlamış sonraki meselelere dolayısıyla da Allah'ın cüz'îleri bilmesi konusuna değinmemiştir. ${ }^{8} \mathrm{Bu}$ âlimlerden İbn Rüşd, Hocazâde, Ali Tûsî ve Kemalpaşazâde ise Gazzâlî̀yi haklı bulmuşlardır. Mezkûr isimler arasında İbn

${ }^{6}$ İbrahim Hakkı Aydın, "Tehâfüt Geleneği Üzerine Bir Değerlendirme", Atatürk Üniversitesi İlahiyat Fakültesi Dergisi 26 (Aralık 2006), 62.

${ }^{7}$ Muslihuddin Mustafa b. Yûsuf Hocazâde, et-Tehâfüt fi'l-muhâkemeti beyne'l-Gazzâlî ve'l-felâsife, thk. Luay Hatem Yaqoob (Beyrut: Dâru'r-risâleti'l-âlemiyye, 2018); Şemseddin Ahmed Kemalpaşazâde, Hâssiye alâ Tehâfütü'l-felâsife, çev. Ahmet Arslan (Ankara: Kültür ve Turizm Bakanlığı Yayınları, 1987).

${ }^{8}$ Muhyiddîn Muhammed b. Alî Karabâĝî, Ta'lika alâ șerhi Tehâfüti'l-felâsife li Hocazâde, çev. Abdurrahim Güzel (Ankara: Kültür ve Turizm Bakanlığı Yayınları, 1991). 
Rüşd'ün Gazzâlî̀yi haklı bulması diğerlerine göre daha farklı saiklerledir. İleride buna temas edilecektir.

Allah'ın cüz'îlere dair bilgisiyle ilgili tartışmaların yürütüldüğü diğer mecra ise, el-Isşârât ve't-tenbîhât ve şerhleridir. Bu esere Fahreddin Râzî ve Nâsiruddîn Tûsî gibi iki önemli âlim şerh yazmıştır. Tûsî șerhini bir anlamda Râzî̀ye reddiye olarak kaleme almıştır. Daha sonra Kutbuddin Râzî iki şerhi mukayese ederek bir hașiye yazmıștır. Makalede temellendirilmeye çalışılacak olan iddianın kaynağı da işte bu haşiyedir.

İbn Sînâ Vâcibu'l-vücûd'un mücerret bir varlık dolayısıyla akıl olduğunu, mücerret her varlığın akleden olduğunu, akleden varlıkların kendilerini aklettiğini yani Zorunlu'nun akıl, âkil ve makul olduğunu söyledikten sonra O'nun kendisi dışındaki varlıkların tamamını da bildiğini iddia etmiştir. Ancak mesele şu ki Zorunlu'nun dışında kalan varlıklardan bazıları zamanın taalluk ettiği değişken ve duyusal varlıklardır. Vâcibu'l-vücûd ise mutlaktır ve değişkenliği kabul etmez ve duyusal bilgiyi idrak etmez. Buna göre İbn Sînâ'ya göre Vâcibu'l-vücûd nasıl olur da bu değişken varlıkları bilebilir? İbn Sînâ bu soruya O'nun bütün varlığı küllî olarak bir defada bildiğini söyleyerek cevap vermiştir. Ancak İbn Sînâ'nin bu cevabı başta Gazzâlî olmak üzere pek çok âlim tarafından doğru bulunmadığı gibi üstüne üstlük Vâcibu'l-vücûd'un varlıklardan bazılarını bilmediği sonucuna götürdüğü iddia edilmiștir. Bazı âlimler ise İbn Sînâ'nın cevabını doğru bulmuş ve eleștirileri kabul etmemişlerdir. İşte İbn Sînâ'nın cevabı ve karşılıklı eleştirilerin neticesinde ortaya çıkan, üzerinde tartışılan problem özet olarak budur.

İbn Sînâ'nın cevabının doğru olduğunu söyleyenler bu cevabı eleştirilere karşı savunurken görebildiğimiz kadarıyla üç farklı izah ortaya koymuşlardır. Bu izahlardan birincisini İbn Sînâ'nın kendisi de yapmaktadır. İzah özetle şöyledir: Vâcibu'l-vücûd bütün varlığın sebebidir ve kendisinin varlığın sebebi olduğunu ve kendisini bilmektedir. Sebebi bilen sonucu da bilmelidir. Dolayısıyla 0, bütün varlığı bilmektedir. Bu izahı sonraki pek çok âlim de kullanmıştır. İkinci izah Tûsî̀ye aittir. Kısaca o şöyle söyler: Vâcibu'l-vücûdbütün varlığın mahiyetini ve sıfatlarını bilmektedir. Dolayısıyla bütün varlığı da bilmektedir. Üçüncü ve son izah Kutbuddin Râzî̀ye aittir. Ona göre Vâcibu'l-vücûd bütün varlığı önceden bilmektedir. Bu izahlara dair detaylı bilgi ileride verileceği için burada bu kadarıyla iktifa ediyoruz.

Makalede yapmayı amaçladığımız şey Kutbuddin Râzî’nin meseleye dair izahının diğer izahlar arasında neden tercih edilebilir olduğunu ortaya koymak olacaktır. Çünkü bu izahta Allah'a çokluk isnat edilmemesi adına İbn Sînâ'nın O'nun cüz'îleri küllî olarak bildiği görüşünün aslında Allah'ın her şeyi ezelde küllî olarak bildiği manasına geldiğinin işaretleri vardır. Biz de bu işaretlerden yola çıkarak İbn Sînâ'nın görüşünün nasıl yorumlanmasına gerektiğine dair bir fikir ileri sürmekteyiz.

\section{1. İbn Sînâ'ya Göre Allah'ın Cüz'îleri Bilmesi}

İbn Sînâ, Allah'ın cüz'îleri bilmesi meselesinde büyük bir tartışmayı başlatacağını önceden sezmiş gibidir. Bu nedenle de meselenin ağır, kendi görüşünün ise 
müşkilolduğuna işaretle "(Allah'ın cüz'îleri küllî olarak bilmesi) tasavvuru için latîf bir mizaca ihtiyaç duyulan acaipliklerdendir" demiştir. ${ }^{9}$ Bununla birlikte eserlerinde mesele hakkındaki görüșünü izah etmekten de geri durmamıștır.İbn Sînâ'ya göre Allah cüz'îleri bilmektedir hatta bilmek zorundadır. Ancak İbn Sînâ nezdinde mesele daha bu ilk cümlenin yüklemiyle başlamaktadır. Bilmek fiili Allah için kullanıldığında yani Allah'ın bilmesi denildiğinde ne kastedilmektedir? İkinci mesele Allah'ın neyi bildiğidir. Üçüncü mesele O'nun bildikleri arasında yer alan cüz'înin ne olduğudur. Dördüncü mesele cüz'îlerin bilinirliğidir. Beşinci mesele Allah'ın cüz'îleri nasıl bildiğidir. Şimdi ilk meseleden başlayarak sırasıyla bu meselelerin İbn Sînâ tarafından nasıl izah edildiğini ele alalım.

Öncelikle İbn Sînâ'nın Allah'ın bilmesiyle insanın bilmesini ayırdığını belirtmemiz gerekir. İnsan, kavramları bir süreç dâhilinde, değişken ve zamansal olanları da duyularla bilir. Fakat Vâcibu'l-vücûd mahza akıldır. ${ }^{10}$ Çünkü her yönüyle maddeden ayrıktır/soyuttur. ${ }^{11}$ Dolayısıyla akıl mücerret hakikatten ibarettir. ${ }^{12}$ Mahza akıl olan ve maddeyle hiçbir ilişkisi olmayan bir varlığın bilme yöntemi akletmektir. Bizim gibi duyulara sahip olmadığı için başka türlü bir bilgi elde etme yöntemine sahip değildir. Vâcibu'l-vücûd eşyayı bizim gibi duyularıyla idrak etmez. ${ }^{13}$ Çünkü 0 , maddeden ve maddi olandan ayrıktır; maddi olanlarla hiçbir bağ ve bağlantısı yoktur. Duyular ise ancak maddi olanın bilgisini elde edebilirler. $\mathrm{Bu}$ sebeple Vâcibu'l-vücûd için geriye tek bir yöntem kalmaktadır ve o da akletmektir.

Bilme yöntemi akletmekten ibaret olan Vâcibu'l-vücûd İbn Sînâ'ya göre neyi akletmektedir? Ona göre Vâcibu'l-vücûd zatından başlamak suretiyle her şeyi akletmektedir. ${ }^{14}$ Vâcibu'l-vücûd öncelikle zatını akleder. Tabi burada belirtmemiz gerekir ki öncelik zamansal bir öncelik değil ontik bir önceliktir. Çünkü Vâcibu'lvücûd zamana bağlı olarak akletmez. ${ }^{15}$ Böylece 0 , akleden olur. Çünkü Vâcibu'lvücûd'un Zat'ı olan mücerret hakikat O'nun için gizli değildir; O'nun sebebiyle vardır. ${ }^{16} \mathrm{Bu}$ mücerret hakikat ancak O'nunla hâsıl olduğuna göre 0 , akledilendir. ${ }^{17}$ Vâcibu'l-vücûd'un akıl, akleden ve akledilen olması aynı şeydir; O'nda çokluk oluşturmaz. Nitekim nasıl ki insan kendisini düşündüğünde bu eylem onda çokluk oluşturmuyorsa O'nun akıl, âkil ve makul olması da çokluk oluşturmaz. ${ }^{18}$

Vâcibu'l-vücûd'un akeltmesi ve akleden olması İbn Sînâ'nın O’nun varlığı

\footnotetext{
${ }^{9}$ Ebû Alî el-Hüseyn b. Abdillâh b. Alî İbn Sînâ, eș-Şifâ -İlâhiyyat- (Kum: Mektebetü semâhat, 2012), 359;

Kâdî Zeynüddîn Ömer b. Sehlân es-Sâvî İbn Sehlân, Hasan el-Merâğî, Nehcü't-takdîs (Tahran: Şems-i Tebrîzî, 2006), 32.

10 İbn Sînâ, eş-Şifâ -İlâhiyyat-, 356; Ebû Alî el-Hüseyn b. Abdillâh b. Alî İbn Sînâ, Kitâbü'n-necât (Tahran: İntişârât-ı dânişnâ, ts.), 650.

11 İbn Sînâ, eş-Şifâ -İlâhiyyat-, 356.

12 Ebû Alî el-Hüseyn b. Abdillâh b. Alî İbn Sînâ, er-Risâletü'l-arșiyye, thk. İbrahim Hilâl (Mısır: y.y., ts.), 25.

13 İbn Sînâ, et-Ta'lîkât, 81.

${ }^{14}$ Ebû Alî el-Hüseyn b. Abdillâh b. Alî İbn Sînâ, el-Isşârât ve't-tenbîhât -İlâhiyyât-, thk. Süleyman Dünya (Beyrut: Müessesetü'n-Nu'mân, 1993), 297.

15 İbn Sînâ, et-Ta'lîkât, 13.

16 İbn Sînâ, er-Risâletü'l-arşiyye, 25.

17 İbn Sînâ, er-Risâletü'l-arşiyye, 25.

18 İbn Sînâ, er-Risâletü'l-arşiyye, 25.
} 
nasıl bildiğine dair görüşü açısından önem arz etmektedir. Çünkü mahza akıl olan Vâcibu'l-vücûd'un kendisini akletmesi aynı zamanda varlığı da akletmesidir. 0 , kendisini aklederek akleden olduğunda varlığı aklederek de akleden olmuş olmaktadır. O, varlığın ilkesidir. Her şey varlığını O’na borçludur. ${ }^{19}$ Dolayısıyla O, kendisini aklederek aynı zamanda varlığı da akletmektedir. Varlığı akletmesi demek de cüz'îler dâhil her şeyi akletmesi demektir. Böylece Vâcibu'l-vücûd'un neyi bildiği sorulduğunda İbn Sînâ'nın cevabı Sebe suresi 3. ayete ${ }^{20}$ atfen zerre dahi dıșarıda kalmadan ${ }^{21}$ her şeyi bildiği șeklindeolacaktır. Böyle bir cevap İbn Sînâ savunucularını tartışmada bir adım ileri taşımış gibi görünmektedir. Çünkü her şeyi bildiğini söylemek Vâcibu'l-vücûd'uncüz'îlere dair bilgisinin olduğunu söylemektir. Bu açık beyan Gazzâlî taraftarlarını ikna etmemiștir. Bunun nedeni İbn Sînâ'nın Vâcibu'lvücûd'uncüz'îleri bildiğini açıkça ortaya koyan ifadelerini gölgeleyen başka beyanları vardır. İbn Sînâ yine açıkça Vâcibu'l-vücûd'un oluş-bozuluş âlemine ait cüz'îleri bilmediğini söylemiştir:

“Vâcibu'l-vücûd'un, güneș tutulması gibi, işaret edilen olması bakımından cüz'îleri bilmesi mümkün değildir. Mesela: "Bu güneș tutulması" diyerek işaret ettiğimizde ya da "bugün gerçekleşiyor olan güneș tutulması" veya "yarın gerçekleşecek olan güneş tutulması" dediğimizde Vâcibu'l-vücûd (ki O'nun bunları bildiğini söylediğgimizde) bunları falanca zamandan sonra ve falanca hareketten sonra bilmiș olur. Fakat 0 , işaret edilenleri bilemez." 22

Bu pasajda İbn Sînâ'nın Allah'ın neden bunları bilmediğiyle ilgili açıklamasını dikkate almadığımızda, onun Vâcibu'l-vücûd'un bilmediği bir şeyler olduğunu söylüyor olması karşı tarafın iştahını kabartmış ve her șeyi biliyor olduğunu söylemesi dikkate alınmamış hatta Rahim Acar'ın deyimiyle inandırıcı bulunmamıştır. Çünkü İbn Sînâ onlara göre Vâcibu'l-vücûd'un bilmediği bazı şeyler olduğunu düşündüğü halde her şeyi bildiğini söyleyerek bu görüşünü gizlemek istemiştir. ${ }^{23}$

Hakkında yapılan niyet okumalarını bir kenara bıraktığımızda ve sadece söylediklerine baktığımızda İbn Sînâ'nın birbirine muarız iki beyanını görmekteyiz. Bu nedenle burada sorulması gereken sorular şunlardır:

- I İbn Sînâ ve savunucuları ihtilaflı bu iki söylemi nasıl bir araya getirmiş ve birleştirmişlerdir?

- Vâcibu'l-vücûd'un hem her şeyi bildiğini söylemek hem de cüz'îlerden bazılarını bilmediğini söylemek mümkün müdür?

- Cüzîlerden bazılarını bilmediğini söyleyerek aslında başka bir şey mi kastetmektedir?

- Cüz'îlerle kastedilen nedir?

Son sorudan başlayarak İbn Sînâ'nın verdiği cevapları ele almak suretiyle yukarıda bahsettiğimiz meseleleri izaha kavuşturmaya çalışalım.

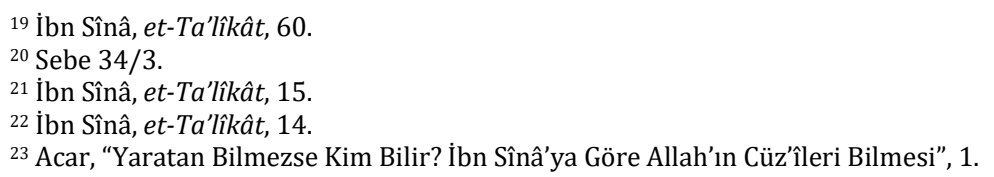


Vâcibu'l-vücûd'un bilgisinin mahiyeti, nelerin O'nun bilgisine dâhil olduğu sorusu zaten tartışmanın temel problemidir. İbn Sînâ'nın Vâcibu'l-vücûd'un cüz'̂̂lere dair bilgisinin nasıl olduğuyla ilgili açıklamaları cüz'îlerle ne kastettiği sorusunu gündeme getirmektedir. Tabiî olarak cüz'î denildiği zaman bunun mukabili olan küllî kavramı da gündeme gelmektedir. Bu nedenle öncelikle İbn Sînâ'ya göre küllînin ne olduğunu belirtmek yerinde olacaktır. Ona göre küllî eklerinden soyutlanmış mahiyettir. Bu söz şöyle bir örnekle açıklanabilir:

İnsan olmak bakımından insan umum, husus, tek veya çok olmak bakımından insandan farklı bir şeydir. Çünkü insan olmak bakımından insan başka bir şart olmaksızın insandır. Onun âmm, hâs, tek ve çok olması insan olması üzerine zait şeylerdir. Bunun manası şudur: Bunlardan hiçbiri insanlık mefhumuna dâhil değildir. Bilakis insanlığın insanlık olması ancak insanlık olması sebebiyledir. Teklik insanlığa dâhil bir sıfattır. Insanlık onunla beraber tek olur. Yine insanlık tanım itibariyle çok olan şeylere mutabık olduğu için âmm olur. Fakat insanlık kendinde yine sadece insanlıktır. ${ }^{24}$

Cüz'̂̂lerin şahsî niteliklerinden arındırılmış hali anlamına gelen küllî akıl sahibi herkes tarafından akledilebilir niteliktedir. Küllînin akledilebilir olması, bilmesi akletmesinden ibaret olan Vâcibu'l-vücûd'un da küllî olanı bildiği sonucunu ortaya çlkarır. Fakat mesele sadece bundan ibaret değildir. Küllînin akledilebilir olmasının yanı sıra İbn Sînâ'ya göre akledebilir olanlar da sadece küllîlerdir. Bu durumda cüz'îler nasıl akledilmektedir?

Cüz'îler İbn Sînâ nezdinde türünün tek örneği olan cüz'îler ve birden fazla örneği olan cüz'îler şeklinde ikiye ayrılmaktadır. Türünün tek örneği olan cüz'îler ay-üstü âlemin fertleridir. Türüne ait nitelikleri taşıyan tek ferttir. ${ }^{25}$ Tam da bu nedenle onlar aynı zamanda küllîdir. Çünkü türünün tek örneği olan bir varlık hakkında belirteç kullanılmaz, ona işaret edilmez. Mesela Venüs İbn Sînâ'ya göre türünün tek örneği bir varlıktır. Venüs'ten bahsederken "bu Venüs" ya da "yuvarlak Venüs" veya "güneş sisteminde bulunan Venüs" diye bahsetmeyiz. Bu nedenle Venüs türünün tek örneğidir ve küllîdir, değişmez. Buna göre İbn Sînâ için bir anlamda tek cüz'î vardır ki o da türünün tek örneği olmayan, ay-altı âlemin yani oluşbozuluş âleminin fertleridir.

Fahreddin Râzî, İbn Sînâ'nın Allah'ın cüz'̂̂leri bilmediğini söylediğini iddia ettiği için Gazzâlî’yi eleştirmiştir. Eleştirinin odak noktası Gazzâlî’nin İbn Sînâ hakkında "Allah'ın cüz'îleri bilmediğini söylemektedir" demesidir. Fahreddin Râzî, Allah'ın kendisini bildiğini herkesin kabul ettiğini, cüz’îyi bilmenin manasının bir varlığın kendisini bilmesi olduğunu söylemiștir. Fahreddin Râzî̀ye göre Gazzâlî'nin iddiası aslında İbn Sînâ'nın Allah'ın değișken cüz'îleri yani ay-altı alemîn fertlerini bilmediğini söylemesi olmalıdır. Yani filozoflar hakkında dile getirirlecek doğru iddia, onların, Allah Teâlâ'nın değişkenleri değişken olmaları açısından bildiğini,

${ }^{24}$ Fahreddin Muhammed b. Ali el-İsferâyînî Nîsâbûrî, Şerhu Kitâbü'n-necât (Tahran: İncemin âsâr ve mefâhir-i ferhengî, h. 1383), 233, 234.

25 Fehrullah Terkan, “İbn Sînâ, Zorunlu Varlık’ın Cüz'iyyâtı Bildiğini Tutarlı Olarak İddia Edebilir mi?”, Uluslararası İbn Sînâ Sempozyumu, ed. Mehmet Mazak (İstanbul: İstanbul Kültür A.Ş. Yayınları, 2009), 6. 
cismânîleri de kendilerine has belirli ölçülere sahip olmaları hasebiyle bildiğini inkâr ettikleridir. ${ }^{26}$ Ancak biz, Gazzâlî̀nin türünün tek örneği olan cüz'îleri bir anlamda küllî sayarak cüz'îlerle değişken cüz'îleri kastettiğini düşünüyoruz. Bu nedenle Fahreddin Râzî'nin eleștirisinin yersiz olduğunu söyleyebiliriz. Birden fazla örneği olan cüz'̂̂ler yani değişken cüz'îler ay-altı âlemin fertleridir. Türünün niteliklerini paylaşan bu tikeller ayrıca zamansaldırlar. ${ }^{27}$ Değişken ve zamansal olan bu cüz'îler aynı zamanda da maddeyle ilişsili ve duyusaldırlar; kendilerine işaret edilir, haklarında konuşurken belirteç kullanılır. İbn Sînâ'nın "Allah'ın bilemeyeceğini" söylediği cüz'̂̂ler işte bunlardır.

Filozofların Allah'ın cüz'îleri bilmesinin problem doğuracağına dair en güçlü argümanları bir örnekle şöyle açıklanabilir: Allah'ın Zeyd'in bir mekânda oturuyor olduğunu bildiğini farz ettiğimizde;Zeyd o mekândan kalktığında ki Allah, Zeydi oturuyor olarak bilmektedir, bu bilgisi devam ederse cahil olur. Allah Teâlâ'nın cahil olması muhaldir. Devam etmiyorsa bilgisinde değişim meydana gelmiş olur. Değişim de Allah Teâlâ için muhaldir. ${ }^{28}$

Gazzâlî, Râzî vb. âlimlerin iddialarının aksine İbn Sînâ ay-üstü ay-altı ayrımı yapmaksızın bütün cüz'̂̂lerin Allah tarafından akledildiğini söylemiştir. Bir şeyin akledilmesinin önündeki engel onun maddeyle ilişkisidir. Maddeden soyutlanan her şey akledilebilir. ${ }^{29}$ Dolayısıyla cüz'̂̂lerin akledilebilmesi için maddeden mücerret olması gerekir. Fakat cüz'̂̂ler için böyle bir şey söz konusu değildir. 0 halde cüz'îler Allah tarafından nasıl akledilirler? İbn Sînâ'nın bu soruya cevabı nettir: Cüzîler Allah tarafından küllî olarak bilinirler. ${ }^{30}$ Cüz'îler kendisine ișaret edilmeyecek ve kendisine işaret edilene dayanmayacak şekilde küllî olarak bilinebilirler. Mesela: Sokrat hakkında o, nübüvvet iddia edendir, zulmen öldürülendir, kralın oğludur dediğinde bunların hepsi özel bir şahsa değil birçok kimseye hamledilebilir. Onun hakkında o, bu insanın oğludur dediğinde ise Sokrat kendisine işaret edilen olur çünkü kendisine işaret edilene dayanmaktadır. ${ }^{31}$ Fakat İbn Sînâ'nın cevabı net olsa da mana bakımından net olduğu pek söylenemez. Ona küllî olarak bilmek nedir diye sorulduğunda sebepleri ve illetleriyle bilmek anlamına geldiğini söyleyecektir. ${ }^{32}$ Sebepleriyle bilmenin ne demek olduğu sorulduğunda İbn Sînâ, küllî olarak bilmeyi sebepleriyle bilme, sebepleriyle bilmeyi ise küllî olarak bilme olarak açıklamaktadır. ${ }^{33} \mathrm{Bu}$ açıklama kısırdöngü oluşturan ve muğlak bir açıklama olarak görülmüș ve hasımları asla tatmin etmemiş hatta sözün uzatılarak asıl meramın gizlenmesi olarak algılanmıştır.

Vâcibu'l-vücûd, İbn Sînâ'ya göre, Zat'ını bildiğini ve nasıl bildiğini yukarıda aktarmıştık. O'nun Zat'ı her şeyin varlık sebebidir. Her şeyin varlığı O'na bağlıdır

\footnotetext{
${ }^{26}$ Muhammed b. Ömer b. Hüseyn Fahreddin Râzî, el-Metâlibu'l-âliyye mine'l-ilmi'l-ilâhiyye, thk. Ahmed Hicâzî es-Sefâ (Beyrut: Dâru'l-kitâbi'l-Arabî, 1987), 3/151.

27 Terkan, “İbn Sînâ, Zorunlu Varlık'ın Cüz'iyyâtı Bildiğini Tutarlı Olarak İddia Edebilir mi?”, 349.

${ }^{28}$ Fahreddin Râzî, el-Metâlib, 3/ 151.

${ }^{29}$ Hocazâde, et-Tehâfüt fi'l-muhâkemeti beyne'l-Gazzâlî ve'l-felâsife, 243.

30 İbn Sînâ, et-Ta'lîkât, 14.

31 İbn Sînâ, et-Ta'lîkât, 14.

32 İbn Sînâ, et-Ta'lîkât, 29, 81, 115.

33 İbn Sînâ, et-Ta'lîkât, 28, 29.
} 
çünkü $O$ ilk ilkedir. Dolayısıyla O, her şeyin varlık sebebi olduğunu bilir. Sebebi bilenin sonucu bilmesi gerekir. Vâcibu'l-vücûd eşyanın varlık sebebi olan Zat'ını bildiğine göre bu sebebin sonucu olan eşyayı da bilir. ${ }^{34}$ O'nun bilgisi eșyanın varlık sebebi olduğuna göre ${ }^{35}$ eşya, O'nun bildiği şekilde var olmuştur. O’nun bilgisi eșyaya değil eşya 0 'nun bilgisine tabidir. ${ }^{36}$ Bu sebeple 0 , varlığa getirdiği eşyayı bilmelidir. Vâcibu'l-vücûd, varlıkları bizim duyuyla idrak ederek ve onlara işaret ederek bilmemiz gibi bilmez. Bilakis 0, cüz'îleri ve şahsîleri, onları kendisine ulaştıran, kendisi tarafından var edilen sebeplerle bilir. Bu sebepler bu cüz'̂̂leri ve şahsîleri kendilerine işaret edilen mütehayyil olmaları bakımından içermez. Vâcibu'l-vücûd, bu şahsı onu şahıslaştıran illetleri ve sebepleriyle bilir. Böylece şahıs değişse ve iptal olsa bile O'nun bilgisi değişmez. 0 , bu şahsı, onun kendisine işaret edilen şahsî olduğunu, fasit ve değişken olduğunu bilir. Fakat şahsın fesadı ve değişmesiyle O'nun bilgisi değişmez. 0 , onun, kendisi tarafından yaratılan bütün hallerini bilir; onun kendisi tarafından yaratılan olduğunu bilir; ona dair bilgisi değişmez çünkü onu sebepleriyle bilir; onun yokluğunu kendi kaim kıldığı sebepleriyle bilir. ${ }^{37}$

İbn Sînâ'nın "Allah oluş-bozuluş âlemine ait cüz'îleri bilmez" 38 dedikten sonra onları nasıl bildiğine dair yaptığı bu açıklama hiç kimseyi tatmin etmemiştir. Çünkü açıklama kapalıdır. Açıklamada çok fazla tekrar vardır. İbn Sînâ pek çok defa Vâcibu'l-vücûd'uncüz'îleri sebepleriyle, küllî olarak bildiğini söylemiştir. Ancak izahı yeterince açık olmadığı için tatminkâr bulunmamıştır. Bilhassa tatmin olmayan hasımlar küllîlerden başka bir şey bilmeyen Vâcibu'l-vücûd'un hiçbir şey ifade etmeyen bir istidlalle cüz'̂̂leri bildiğini iddia etmenin aslında O'nun cüz'îleri bilmediğini anlamına geldiğini söylemişlerdir. Her ne kadar Rahim Acar, izah edilemeyen bir iddianın ya da söylemin zıddına tekabül etmeyeceğini söylese de ${ }^{39}$ hasımlar tarafından bu durumun dikkate alındığını söylemek mümkün değildir. Çünkü Acar'ın sözleri İbn Sînâ'nın görüşüne iyimser bir bakışla yaklaşıldığında geçerli olur. Şöyle ki bir katl zanlısının katil olmadığına dair verdiği ifadede bazı noktaları birleştirememesi, bazı güçlü deliller getirememesi onun katil olduğunu göstermez. Bununla beraber aynı zanlının ifadesinde çelişkiler bulunması onu birinci sırada zanlı yapar. Bu nedenle Gazzâlî ve taraftarları İbn Sînâ'nın izahının sadece yetersiz olduğunu değil çeliş̧iler barındırdığını da söylemektedir. Aşağıda Gazzâlî ve diğerlerinin bu konudaki açıklamalarına yer verilecektir.

\section{Gazzâlî’nin İbn Sînâ’yı İthamı}

Gazzâlî Tehâfütü'l-felâsife'nin on üçüncü bölümünde mezkûr esere nazaran ikinci kere İbn Sînâ'yı tekfir eder nitelikte sözler sarf etmektedir. Gazzâlî’nin bu seferki tekfir sebebi İbn Sînâ'nın Allah'ın cüz'îlere dair bilgisiyle ilgili açıklamalarının Allah'ın cüz'îleri bilmediği anlamına gelmesidir. Burada sorulması gereken iki

\footnotetext{
34 İbn Sînâ, er-Risâletü'l-arşiyye, 26.

35 İbn Sînâ, et-Ta'lîkât, 29.

36 İbn Sînâ, er-Risâletü'l-arşiyye, 26; İbn Sînâ, et-Ta'lîkât, 116.

37 İbn Sînâ, et-Ta'lîkât, 81.

38 İbn Sînâ, eş-Şifâ -İlâhiyyat-, 359.

39 Rahim Acar, "Allah'ın Cüz'îleri Bilmesi: Klasik İbn Sînâ Yorumunun Değerlendirilmesi”, Divan: Disiplinlerarası Çalışmalar Dergisi 20 (Haziran 2006), 112, 113.
} 
soru vardır: 1. Gazzâlî İbn Sînâ'nın Allah'ın cüz'îleri bilmediğini söylediği sonucuna nereden varmıştır? 2. Gazzâlî İbn Sînâ'yı tekfir etmiş midir? Cevabı birinci soruya nazaran daha kısa olduğu için önce ikinci soruyu cevaplamanın yerinde olacağını düşünüyoruz. İbn Rüşd Faslu'l-makal'de tekfir etmediğini söylemiştir. Gazzâlî bu konuda Tehâfüt'de açık bir tekfir ifadesi kullanmamıştır. Fakat o zımnen tekfir etmiştir. Şöyle ki onların sözlerinin Allah'ın Zeyd'in imanı ya da küfrü gibi şahsi bir meseleyi hatta peygamberliğini ilan eden şahsın kim olduğunu dahi bilemeyeceği anlamına geldiğini söylemiștir. Bunun onların itikadı olduğunu ve bu itikatla dinleri temelinden yıktıklarını ifade etmiştir. ${ }^{40}$ Gazzâlî burada özellikle itikat kelimesini kullanmıştır. Çünkü onların bu görüşle bir hataya düştüklerini değil bunu inanç meselesi yaparak dini temelinden yıktıklarını söylemiștir. Bu da onun Tehâfüt’te İbn Sînâ'yı açıktan olmasa da zımnen tekfir ettiğini gösterir. Bunun yanında Gazzâlî elMukız'da isim vermeden bu görüşte olanların kâfir olduklarını açıkça söylemiştir. ${ }^{41}$ Tabiî burada isim zikretmemesi kimi tekfir ettiği yönünde bir soru işareti oluştursa da "Onların Allah Teâlâ küllîleri bilir; cüz'îleri bilmez sözü" 42 demesi kimi kastettiğini net bir şekilde ortaya koymaktadır.

Birinci sorunun cevabına geldiğimizde Gazzâlî Tehâfüt'te İbn Sînâ'nın görüşünü aktardıktan ve onun sözlerinin Allah'ın cüz'îleri bilmediği anlamına geldiğini birkaç örnek üzerinden gösterdikten sonra neden böyle söylediğinin açıklamasını yapar. Öncelikle İbn Sînâ'nın Allah'ın değişken şeyleri bilmeyeceğini, bildiği takdirde Zat'ında değișim olacağını söylemesi yanlıștır. Çünkü bilene nispetle bilinen, bir cismin kişinin sağında durması gibidir. 0 cisim kişinin soluna geçtiği zaman cisimde değişim olsa da kişide bir değișim olmamış, yerinde olduğu gibi kalmıştır. Değişken cüz'îlerin Allah'a nispeti de böyledir. Onlardaki değișim, onların bilgisine sahip olan Allah'ta bir değişime yol açmaz. ${ }^{43} \mathrm{Bu}$ yüzden ona göre İbn Sînâ'nın Allah'ın cüz'îleri bu nedenle bilemeyeceğini iddia edip sonra da nasıl bilmesi gerektiğini temellendirmeye çalışması doğru değildir.

Gazzâlî̀nin İbn Sînâ'ya ikinci cevabı sudur nazariyesi üzerinden olmuştur. Âlem, Allah'tan, ontik olarak sonradan meydana gelmişse de zaman olarak sonradan meydana gelmiş değildir. Çünkü Allah tam illettir. Malulün tam illetten geri kalması ise muhaldir. Buna göre Vâcibu'l-vücûd'dan sudur eden âlem ezelidir. Bununla birlikte âlemde değișimler vardır. Ezelî bir varlığın değişim kabul etmesi mümkün değildir. Çünkü hâdislere mahal olanın kendisi de hâdis olmalıdır. Ezelî bir varlığın değișime mahal olması filozoflara göre mümkünse Allah'ın değișken cüz'îleri bilmesi neden mümkün olmasın? ${ }^{44}$ Gazzâlî daha önceden yakaladığı açığı burada bir kez daha gündeme getirerek filozofları tekrar yıpratmak istemektedir.

40 Ebû Hâmid Muhammed b. Muhammed b. Muhammed b. Ahmed Gazzâlî, Filozofların Tutarsızlığı, çev. Mahmut Kaya (İstanbul: TÜYEK, 2014), 280.

41 Ebû Hâmid Muhammed b. Muhammed b. Muhammed b. Ahmed Gazzâlî, "el-Munkızu mine'd-dalâl", Mecmû'atü resâili'l-İmâmi'l-Gazzâlî, ed. Ahmed Şemseddin (Beyrut: Dâru'l-kütübi'l-ilmiyye, 1988), 42.

42 Gazzâlî, "el-Munkızu mine'd-dalâl", 42.

${ }^{43}$ Gazzâlî, Filozofların Tutarsızlığı, 282.

44 Gazzâlî, Filozofların Tutarsızlığı, 288; Muhammet Caner Ilgaroğlu - Luay Hatem Yaqoob, “Allah'ın Cüz'îleri (Tikeller) Bilmesi Meselesi: İbn Sinâ, Gazzâlî ve Hocazâde’nin Görüşlerinin Karşılaştırılması”, MANAS Sosyal Araştırmalar Dergisi 8/1 (Şubat 2019), 944. 
Âlemin ezeliliği konusunda zaten tekfir ettiği filozofları cüz'̂̂lerin bilinmesi konusunu da ona bağlayarak ikisinden birini terk etmeye zorlamaktadır. Âlemin ezeliliğini kabul etmeleri halinde Vâcibu'l-vücûd'un da değişimi kabul etmesinin mümkün olduğunu kabul etmelerini aksi halde âlemin ezeliliğini de reddetmelerini istemektedir.

Filozofları itham ederken Gazzâlî’nin vurguladığı bir diğer husus cüz'îleri bilmenin Allah'ta çokluk gerektireceğini iddia eden filozofların küllîleri bilmenin de çokluk gerektireceğini gözden kaçırmış olmalarıdır. Filozoflara göre Allah sadece insanlık, canlı vb. kavramaları bilir. Fakat bunlar birer kavramdır ve hepsi ayrı ayrı ele alındığında birden fazladır. Böyle bir durumda Allah'ın zatı yine birden fazla varlığa mahal olmuş demektir. İbn Rüşd de Gazzâlî̀yi bu konuda desteklemektedir. İbn Rüşd'e göre türlerin ve cinslerin çokluğu Allah'ın bilgisinde çokluk oluşturur. Bu sebeple muhakkik filozoflar Allah'ın mevcudata dair bilgisini küllî ve cüz'î olarak nitelememektedirler. ${ }^{45}$ İbn Rüşd'ün bu desteği onun, Gazzâlî̀nin de savunduğu, Allah'ın varlığı ezelî olarak tek bilgiyle bildiği görüşüne yaklaştığı izlenimi verebilir. Zira Allah'ın bilgisini küllî ve cüz'î olarak ayırmamak, bir bütün halinde olduğunu söylemek O'nun karşısında varlıkların bir ayırma tabi olmadığını, varlık ayrımı yapanın biz olduğumuzu göstermektedir. Nitekim İbn Rüşd Tehâfüt'te Allah'ın bilgisinin niteliğini araştırmanın doğru olmadığını, çünkü bizim bilgiyi karşılaştırma yaparak elde ettiğimizi ve Allah'ın bilgisine dair karşılaştırmayı ancak kendi bilgimizle yapabileceğimizi, bunun da yanlış bir tutum olduğunu birden fazla kez ifade etmiştir.

İbn Sînâ'nın "Allah'ın cüz'îleri bilir." İfadesi Gazzâlîye göre bir anlam taşımamaktadır. Çünkü o Allah cüz'̂̂leri küllî olarak bilir demiştir. Bunun anlamı şudur: Allah güneșin neden tutulduğunu bilir fakat şu anda güneş tutulması olduğunu bilmez. Gazzâlîye göre küllî olarak bilmenin anlamını bir örnekle izah edecek olursak; mağarada yaşayan ve dışarıyla hiçbir irtibatı olmayan bir astronoma dışarıdan gelen bir adamın "şu anda güneş tutulması var" dediğinde astronomun verdiği "evet, dünya falanca konumda, güneş filanca konumda olduğunda, ay da aralarına girdiğine güneş tutulması olur." cevabı onun şu anda güneş tutulması olduğunu bildiğini göstermez. Astronom güneş tutulmasının sebebini gayet iyi bilmektedir fakat o anda yaşanan cüz'î güneş tutulmasının varlığından haberi yoktur. Dolayısıyla küllî olarak bilme Gazzâlî hatta İbn Rüşd açısından bir şey ifade etmemektedir. Çünkü İbn Rüşd de cüz'î ve küllî bilme tarzının Allah'a uygun olmayan nitelikler olduğunu söylemektedir.

\section{3. İbn Sînâ'ya Rağmen İbn Sînâ'yı Savunmak}

Gazzâlî̀nin yeren ve tekfir eden tutumuna ve pek çok âlimin onu desteklemesine rağmen İbn Sînâ'yı savunanlar da olmuștur. Makalemizin temel problemini olușturan İbn Sînâ'nın nasıl izah edilmesi gerektiği düşüncesine katkı yapmak isteyen isimler arasında Tûsî ve Kutbuddin Râzî de vardır.Fahreddin Râzînnin İşârât

\footnotetext{
${ }^{45}$ Muhammed b. Ahmed b. Muhammed el-Kurtubî İbn Rüșd, Tehâfütü't-Tehâfüt (Beyrut: Dâru'l-kütübi'lilmiyye, 2014), 307.
} 
şerhini dikkate alan Tûsî, İbn Sînâ'nın Allah'ın cüz'îleri küllî olarak bildiğine dair yaptığı açıklamayı șerhinde açıklamış, Kutbuddin Râzî de buizahı tetkik ederek uygun olup olmadığını söyledikten sonra kendi izahını yapmıștır.

Fahreddin Râzî ve Nasîruddin Tûsînnin şerhleri, İbn Sînâ'nın el-İsârât ve'ttenbîhât adlı eserinin öne çıkan şerhlerindendir. Birçok konuda İbn Sînâ'ya muhalefet etse de Fahreddin Râzî'nin, iyi bir İbn Sînâ okuyucusu ve onu en iyi anlayan âlim olduğunu söylemek mümkündür. Hemen her eserinde İbn Sînâ'ya ve görüșlerine atıf yapmıştır. Özellikle de İşârât şerhiyle İbn Sînâ'nın anlașılmasına büyük katkı sağlamıştır. Diğer taraftan Fahreddin Râzî̀nin İbn Sînâ için yaptığını Fahreddin Râzî için yapan, kitabını şerh eden ve eleștiren aynı zamanda da İbn Sînâ takipçiliği ile şöhret bulmuş Nasîruddin Tûsî, İbn Sînâ'nın İşârât'ına bir şerh yazmıștır. Bu iki önemli âlimin İbn Sînâ'nın Allah'ın cüz'îleri bilmesi konusunda ne demek istediğine dair yaptıkları açıklamaları oldukça önemlidir. Bununla beraber Fahreddin Râzî ve Nasîruddin Tûsî'nin Işsârât şerhleri denilince akla gelen âlim ve eseri Kutbuddin Râzî ve el-İlâhiyyât mine'l-muhâkemâti beyne Şerhayi'l-İsârât'tır.

Bu üç âlimin mesele hakkında şerhlerinde ne söylediklerini ve İbn Sînâ'yı savunan Tûsî ve Kutbuddin Râzî arasından Kutbuddin Râzînnin görüşünün neden doğru olduğunu açıklamaya çalışacağız. Bunun için öncelikle İbn Sînâ'nın İşârât'ta Allah'ın cüz'îleri bilmesi hakkında ne dediğine bakmamız gerekiyor.

Güneş tutulması gibi cüz'î şeyler, kendisini, kendisiyle şahsileştiği türünün ilkesine mensup kılan sebeplerinin gerektirmesi açısından, küllî olarak akledilebilirler. Bu güneş tutulmasının vukuu cüz'î sebeplerinin onu sağlaması sebebiyle ve aklın onu ihata etmesiyle akledilebilir. Akıl onu küllîleri aklettiği gibi akleder. Bu (küllî) akletme hakkında "şimdi oluyor", "ondan önce oldu" ya da "ondan sonra olacak" șeklinde hüküm verilen zamanın taalluk ettiği cüz'î idrakten farklıdır. Bilakis cüz'î güneș tutulması küllî olarak şöyle akledilir: Ay, falanca cüz'î vakitte falanca bir cüz'î mevkide bulunduğunda güneş tutulması vaki olur. Küllî şekilde aklettiğinde Evvel indinde "bu olmuştur" ya da "bu olmamıştır" șeklinde bir ihata yoktur. Çünkü aksi halde idrak edilenin hudûsuyla idrak hudûs eder ve onun zevaliyle de ortadan kalkar. (Evvel için böyle bir şey söz konusu değildir.) ${ }^{46}$

İbn Sînâ Issârât'ta da daha önce onun diğer eserlerinden aktardığımız ve açıkladığımız üzere Allah'ın cüz'îleri zamansal olarak değil küllî şekilde, sebepleriyle bildiğini söylemiştir. Bunu da yine güneş tutulması örneğiyle ifade etmiştir. Ancak Gazzâlî’nin de ifade ettiği üzere kanaatimizce bir șeyin sebeplerinin bilinmesi o şeyin bilinmesini zorunlu kılmaz. İbn Sînâ'nın "Sebepleri bilmek sonuçları bilmeyi gerektirir" tezinin geçerli olmadığını izah eden Terkan'a göre Vâcibu'lvücûd küllî yolla biliyorsa, zamansal cüz'îleri bilemez. Eğer bilgi küllî ise, cüz'îleri kapsayamaz; eğer cüz'îleri kapsarsa, o bilginin öz niteliği küllî olmaz. Eğer küllî, sıfatları, cins ve türleri kapsıyorsa, zamana ve mekâna endeksli önermeler dışarıda bırakılmaktadır. ${ }^{47}$ Dolayısıyla İbn Sînâ'nın Allah'ın cüz'îleri küllî şekilde bildiği iddiasına dair açıklamaları çelişkiler barındırmaktadır. Bununla beraber onun Al-

46 İbn Sînâ, el-İşânât, 286-288.

47 Terkan, “İbn Sînâ, Zorunlu Varlık’ın Cüz’iyyâtı Bildiğini Tutarlı Olarak İddia Edebilir mi?”, 356. 
lah'ın cüz'îleri bilmediğini düşündüğü kanaatinde de değiliz. 0 halde İbn Sînâ'nın açılklamalarına rağmen onun Allah'ın cüz'îleri değişmeden ve cehle düşmeden nasıl bilebildiğinin açıklamasının yapılması ya da İbn Sînâ'nın küllî olarak bilmekle ne kastettiğinin belirlenmesi gerekmektedir.

İşârât üzerinden İbn Sînâ'yı görüșünü şerh etme denemesi yapan Tûsî ve Kutbuddin Râzî arasından Râzî’nin açıklamlarındaisabetli olduğunu düşünüyoruz. Ancak yine de Tûsî̀nin açıklamasının içeriğini bilmek diğerinin neden doğru olduğuna dair daha iyi bir yorum şansı verecektir.

Tûsî şerhine küllî ve cüz'î idrakin ne anlama geldiğini söyleyerek başlamıştır. Ona göre "Şu insan şu sözü șu vakitte söylüyor." sözümüz cüz’̂̂, "İnsan sözü bir vakitte söyler." sözümüz ise küllîdir. ${ }^{48}$ Burada görüldüğü üzere her iki cümlede özne, nesne ve zarf aynı kelimelerden oluşmaktadır. Farklı olan birincide hepsinin belirli olması, ikincisinde ise genel kipler kullanılmış ve bir belirleme yapılmamış olmasıdır. Tûsî̀ye göre birinciyi ikincisinden farklı kılan asıl unsur ise ikincisinin tanımlanabilir olmasıdır. İkinciye nazaran birincide yer alan öğelerin hiçbirinin tanımı yapılamaz ve hakkında bir burhan ileri sürülemez. ${ }^{49} \mathrm{Bu}$ nedenle aklın onu kavraması mümkün değildir. Kendisine ancak işaret edilebilen bu öğeler duyuların alanına girerler. Onların idrakini duyular yapabilir. Bir tabiata sahip olan bu cüz'îler şahıslarından dolayı sahip oldukları bu tabiatla diğerlerinden ayrılır ve duyulara konu olurlar. Bu tabiat sayesinde haklarında hüküm verilebilen bu cüz'îler oluşlarının illetlerini, cüz'î hallerini, birleşme, ayrılma, temas, uzaklaşma, bitişme ve hulul etme gibi hükümlerini herkesin idrak edebilmesini mümkün kılmaktadır. Tûsî’ye göre varlıkların cüz'î hale gelmelerinin sebebi bu tabiattır.

Varlıklar bu tabiatlarından soyutlandığında akledilebilir olmaktadırlar. Çünkü onların mahiyeti küllîdir. Tûsî indinde bu durumu bir örnekle şöyle izah edebiliriz: İnsanlık küllî bir kavramdır. Her insanda bulunmaktadır. Fakat her insanda bulunan ve insan olmasını sağlayan bu kavram aynı değildir. Aynı olsaydı aynı şeyin iki farklı mekânda bulunuyor olması gerekirdi. Bu nedenle teker teker inşalarda bulunan insanlık cüz'îdir. Bir kavram nasıl aynı zamanda hem küllî hem de cüz'î oluyor diye sorulduğunda Tûsî’ye göre onu cüz'îleștiren bir üst paragrafta bahsedilen bu tabiattır. İnsanlığa sahip olan bu insan bu tabiattan soyutlandığında artık küllî biçimde bilinebilir. Çünkü onun küllî olarak bilinmesini engelleyen ve şahsileştirerek duyulara konu yapan tabiatı ortadan kalkmıştır.

Tûsî'nin açıklamaları ilk bakışta İbn Sînâ'nın görüşüne yeni bir boyut kazandırmış gibi görünerek İbn Sînâ savunucularını heyecanlandırmıştır. Fakat dikkatlice tetkik edildiğinde İbn Sînâ'dan çok farklı bir şey söylemediği ortaya çıkmaktadır. Öncelikle İbn Sînâ zaten cüz'îlerin akledilememe sebebinin taşıdıkları tabiat olduğunu söylemiştir. Onun değişken cüzîlerin maddeyle olan ilişkisi nedeniyle akledilemediğini düşündüğünü daha önce ifade etmiştik. Madde bu cüz'̂̂lerin tabiatıdır. Onları şahsîleştirmektedir. Maddeden soyutlandığında akledilmek için bir engeli kalmadığı İbn Sînâ'nın temel argümanıdır. Bu nedenle bize göre Tûsî'nin

\footnotetext{
${ }^{48}$ Muhammed b. Muhammed b. el-Hasen Nasîruddin Tûsî, el-İşârât ve't-tenbîhât me'a şerhi Nasîruddin et-Tûsî, thk. Süleyman Dünya (Beyrut: Müessesetü'n-Nu'mân, 1993), 286.

${ }^{49}$ Nasîruddin Tûsî, Şerhu'l-İşârâti't-Tûsî, 287.
} 
izahatı hedefini bulamamış, eleştirilere yanıt olamamıştır.

Kutbuddin Râzî Issârât haşiyesinde Tûsînnin yaptığı açıklamaların İbn Sînâ'nın görüşünü yansıtmadı̆̆ı gibi onun görüşüyle çeliştiğini de söylemiştir. Çünkü cüz'̂̂leri müşahhas kılan tahsis edicinin ortadan kalkmasıyla varlık zaten küllî olmuş olacağından artık ondan cüz'î olarak bahsedilemez. Bu nedenle Vâcibu'l-vücûd'uncüz'îleri bildiği söylenemez. ${ }^{50}$ İbn Sînâ'nın Allah'ın cüz'îleri sebepleriyle bilediğine dair görüșüne rağmen Tûsî doğrudan cüzînin kendisini bildiğini söyleyerek onun görüşüyle çelişmiştir. Zira cüz'îler İbn Sînâ'ya göre zâtî olarak akledilemezler; sebepleriyle akledilebilirler. Tûsînnin sözleri ise cüz'îlerin zatının akledilebileceği sonucunu doğurmaktadır. Bu yüzden Kutbuddin Râzî Tûsînnin açıklamalarının İbn Sînâ'nın cüz'îlerin bilinmesine dair argümanlarıyla hatta Vâcibu'l-vücûd'un ilminin tahkikine dair sözleriyle çeliştiğini söylemektedir. ${ }^{51}$

Tûsî'nin açıklamalarını doğru bulmayan hatta İbn Sînâ'nın görüşüyle çelişkili olduğunun düşünen Kutbuddin Râzî meseleyi şöyle izah etmiştir:

“Şüphe bırakmayacak doğru açılama şöyledir: Cüz'̂̂lerin zamana müteallik olmaları açısından akledilmeleri değişken,cüz'î șekilde akletmedir. Zamana müteallik olmamaları açsından akletme ise değişmeyen küllî şekilde akletmedir. İbn Sînâ zamana taalluk etmeyen veçhi, sebeplerinden doğan zorunlulukla açıkladı. Sebeplerinin zorunlu kılması açısından cüz'̂́leri akleden kimsede siralanan mevcutların suretleri hâsıl olur ve bunların hallerindeki değișim kesinlikle bunlara dair ilimde değişikliğe yol açmaz. Çünkü bu vecih zamana taalluk etmez. Zaruri olarak bilinir ki malulün tam illetten vücubu zamanî değildir ve onun zamanla taalluku asla bulunmaz."52

Kutbuddin Râzî burada İbn Sînâ'nın açıklamalarına benzer şeyler söylemektedir. Değişken cüz'îlerin sebepleriyle akledilebileceği, temel teori olarak sunulmaktadır. Böyle bir akletmenin değişime yol açmayacağı söylenmektedir. Fakat bu açılklamada önemli bir detay yer almaktadır. Kutbuddin Râzî bir hükümde bulunmaktadır: Sebeplerinin zorunlu kılması açısından cüzîleri akleden kimsede sıralanan mevcutların suretleri hâsıl olur. Bu cümleyi önemli kılan husus akleden kimsede akledilenin suretinin hâsıl olmasıdır. İbn Sînâ da insanların bilme tarzı olan, bir binayı önce akledip sonra meydana getirme örneğinde olduğu gibi, suretlerin önce zihinde canlanmasının Vâcibu'l-vücûd'da da aynı şekilde gerçekleşmesinin zorunlu olduğunu söylemiştir. ${ }^{53} \mathrm{Bu}$ sözün anlamı şudur: Vâcibu'l-vücûd'un akletme tarzı insanın akletme tarzıyla aynıdır. Bu durumda insan varlığı hem aklederek hem de duyularıyla idrak ederek bilme yönteminin fazlalığı açısından Vâcibu'l-vücûd'dan daha avantajlı bir konumda bulunmaktadır. Fakat tabî̂ ki İbn Sînâ'nın ve Kutbuddin Râzî̀nin kastı bu değildir. Onların bu sözle amaçladıkları bir benzetme yoluyla Vâcibu'l-vücûd'un akletmesini açıklamaktır. Yine de bu söz önemlidir. Çün-

50 Ebû Abdillâh Muhammed b. Muhammed Kutbuddin Râzî, el-ïlâhiyyât mine'l-muhâkemâti beyne Şerhayi'l-Işârât, thk. Hâdîzâde Mecîd (Tahran: Merkez-i neşr-i miras-1 mektûb, 1381), 398. Eser bundan sonra Muhâkemâtü Şerhayi'l-Işâ̂ât adıyla anılacaktır.

${ }^{51}$ Kutbuddin Râzî, Muhâkemâtü Şerhayi'l-Isşârât, 398.

${ }^{52}$ Kutbuddin Râzî, Muhâkemâtü Şerhayi'l-İşârât, 398, 399.

53̇̉bn Sînâ, el-İşârât, 276; İbn Sînâ, et-Ta'lîkât, 116. 
kü küllî olarak bilmenin ne anlama geldiğinin ipucunu vermektedir.

İbn Sînâ'nın teorisinde bize göre iki can alıcı kavram vardır: Küllî ve bir defada bilme (def'aten vahideten) kavramları. Ona göre Vâcibu'l-vücûd eşyayı Zat'ında çokluk oluşturmayacak şekilde sebepleriyle bir defada, küllî olarak bilir. ${ }^{54}$ Kanaatimizce İbn Sînâ, belki de Allah'ın cüz'îleri bilmesi meselesine özel olarak, bu kavramları birbiriyle aynı ya da yakın anlamda kullanmaktadır. Bizi bu kanaate sevk eden sebep Fahreddin Nîsâbûrî'nin Kitâbu'n-necât şerhinde külli kavramına dair yaptığı açıklamadır. 0, İbn Sînâ'nın küllî bir kavramı ikiye ayırdığını, bunlardan birinin şartsız olarak eşyada bilfiil olarak, diğerinin ise çokların bilinmesini sağlayan bir vecihle bilkuvve olarak bulunduğunu söylemiştir. ${ }^{55}$ Bunun manasını bir örnekle açıklayacak olursak insanlık bilfiil olarak her insanda bulunur ve her birine "Bu insandır" şeklinde teker teker yüklem olur. Öte yandan erkeklik ise her insanda bilkuvve olarak bulunduğu halde insanlar kendilerinde kadınlık da bilkuvve bulunduğu için bilfiil olarak kadın olabilirler. Dolayısıyla insanın bulunduğu yerde insanlık olmak zorundadır ama erkeklik olmak zorunda değildir. Buna göre Vâcibu'l-vücûd bir insanın erkek veya kadın olacağını bunların bilkuvve mevcut olmasından dolayı bildiği halde onun bilfiil erkek olduğunu erkek olduktan sonra değil olmadan önce bilir. Fakat o insanın erkek olduğunu o insanın erkek olasından bilmesi mümkün değildir. Çünkü Vâcibu'l-vücûd eșyayı eşyadan dolayı değil Zat'ından dolayı bilir. Bu durumda 0 , küllî bir kavram olan ve hariçte bilfiil bulunan bir şeyi biliyor olduğuna göre her bir insanın erkek mi kadın mı olduğunun bilgisine küllî olarak, yani cümleten bir defada sahiptir.

Kutbuddin Râzî Vâcibu'l-vücûd'uncüz'îlerin ezelden ebede hepsini kendi vakitlerinde bildiğini söylemiştir. ${ }^{56}$ Bu söylemin İbn Sînâ'da karşılığı șu pasajdır:

Vâcibu'l-vücûd'un zatı sebebiyle bilmesi eşyayı cüz'îsiyle-küllîsiyle olduğu hal üzere, cüzî̀, küllî, sabit, değişken, olan-bozulan, sonradan olan, yok olan olarak ve yokluğunun sebebiyle; ebedî olanları ebedî olarak, hâdis olanları hâdis olarak; hâdisleri hudûsundan önce, hudûsu anında ve hudûsundan sonra illetleriyle ve sebepleriyle küllî olarak bilmesidir. Bizim eşyayı hudûsundan önce bilmememiz gibi hâdisin yok iken sonradan var olması O'nun için bilgi ifade etmez. Hâdislerin hepsi O'nun için hazırdır çünkü Zat'ı onların sebebidir. ${ }^{57}$

İki âlimin bu sözlerini birbiriyle aynı ya da yakın anlamda kullanılan küllî ve bir defada kavramlarıyla, Gazzâlî̀nin "Allah mevcudatı tek bir bilgiyle bilir"58 sözündeki bu iki kavramı hatırlatan tek bir bilgi kavramıyla ve İbn Sînâ'nın atıfta bulunduğu Sebe suresi 3. ayette geçen “...hepsi apaçık bir kitaptadır.” sözünü birlikte okumanın mümkün olduğunu düşünüyoruz. Böyle bir düşünmenin neticesinde ortaya çıkacak sonuç Vâcibu'l-vücûd'un ebediyen her şeyin bilgisine toplu şekilde sahip olduğudur. Bunu bir film senaryosuna benzetebiliriz. Filmde yer alacak her sahne, eylem, mimik vb. o senaryoda yer almaktadır. Böylece senaryoyu oku-

\footnotetext{
54İbn Sînâ, eş-Şifâ -ílâhiyyat-, 363.

${ }^{55 N i ̂ s a ̂ b u ̂ r i ̂, ~ S ̧ e r h u ~ K i t a ̂ b u ̈ ' n-n e c a ̂ t, ~} 131$.

${ }^{56}$ Kutbuddin Râzî, Muhâkemâtü Şerhayi'l-İşârât, 400.

57 İbn Sînâ, et-Ta'lîkât, 81.

58 Gazzâlî, Filozofların Tutarsızlığı, 284.
} 
yan biri filmi izlemeden önce filmde ne gösterileceğini bilir. İbn Sînâ ve Kutbuddin Râzî'nin de söylediği üzere her şeyin bilgisi O'nda hazır olarak bulunur. ${ }^{59}$ Bilginin bir yerde hazır olarak bulunmasının anlamının bundan başka bir şey olamayacağı fikrindeyiz.

Kutbuddin Râzî̀nin şu pasajda yer alan sözleri Allah'ın bilgisinin zamana müteallik varlıkları tanevülünün izahını yaparken O'nun tek bilgiyle bilmesini tabiri caizse oldu-yaptı, oluyor-yapıyor ve olacak-yapacak şeklinde zaman kipleriyle olamayacağını anlatmaktadır:

Allah Teâlâ cüzî hâdislerin hepsini ve vaki oldukları zamanı bilir. Ancak bu bilme onlardan bazısının şimdi vaki oluyor olması, bazısının geçmişte vaki olmuş olması ve bazılarının da gelecekte vaki olacak olması açısından değildir. Cüz'îlere dair bu bilgi geçmişin, geleceğin ve şimdinin değișmesi hasebiyle değișen bilgi değildir. Bilakis O'nun ilmi zamana dâhil olmaktan münezzehtir. Bununla beraber O'nun ilmi zamanın başlangıcıdır. ${ }^{60}$

Buna göre Allah cüz'îlerin hangi zamanda meydana geleceklerini bilmektedir. Peki, bu zaman nasıl bir zamandır. Allah için dün-bugün-yarın söz konusu olmadı̆̆ına yani zaman içre olmadığına göre 0 , bizim açımızdan oldu, oluyor ve olacak olanları ya olmadı, olmuyor, olmayacak olanları nasıl bilmektedir? Kutbuddin Râzî bu soruya bir örnekle cevap vermektedir. Örneğe göre Zeyd yolda yürümektedir. Az ileride, bir hazine sandığı vardır ve bu sandığın bir ucu gömülü olduğu yerden çıkmıştır. Zeyd o sandığın yanına geldiğinde yüyümesi durur. Biz bütün bunların bilgisine sahip olduğumuz için Zeyd'in hazine sandığını bulduğundan emin oluruz. ${ }^{61}$ Örneğe göre biz Zeyd'in sandığı bulduğu bilgisine götüren bilgilere sahibiz. Bu sebeple de sandığın bulunduğundan emin olabiliyoruz. Hâlbuki sandığın bulunduğunu görmedik; duymadık; hissetmedik. Buna göre Allah her mümkünün bütün sebeplerini ihata ettiğine göre bütün mümkünlerin varlığını ve var olmalarının sebepleri bilinmediği takdirde de varlıklarının imkânsız olduğunu ihata etmesi mümkündür ve gerekir. Allah Teâlâ'nın ilminde imkân yoktur. Çünkü o tereddüt ve şekten münezzehtir. ${ }^{62}$

Kutbuddin Râzî̀nin İbn Sînâ yorumu, İbn Sînâ'nın Allah'ıncüz'îlere dair bilgisi hakkındaki düşüncesinin cebrî kader anlayışını çağrıştıracak biçimde anlaşılmasına kapı aralamaktadır. İbn Sînâ'nın kendi sözleri ise bu kapının daha çok açılmasına neden olmaktadır. İbn Sînâ'nın Allah’ın bilgisinin eşyanın varlık sebebi olduğuna dair görüșü cebr fikrinin İbn Sînâ'daki karşılığıdır. Yukarıda da belirtildiği üzere eşyanın var oluş sebebi O'nun Zat'ını ve Zat'ının eşyanın ilkesi olduğunu bilmesidir. O’nun bilgisi eşyaya göre değil eşya O’nun bilgisine göre ortaya çıkmıştır. İbn Sînâ eşyanın her anlamda O’na bağlığını anlatmak için “O’nun bilgisi, araç ve yenilenen irade olmadan, kendisinden sudur eden mevcudatın varlığının sebebi olunca mevcudat O’nun bilgisine tabi olmuş olur. Bu görüşü O’nun “...ol dememiz-

\footnotetext{
59 İbn Sînâ, et-Ta'lîkât, 81; Kutbuddin Râzî, Muhâkemâtü Şerhayi'l-İşârât, 400.

${ }^{60}$ Kutbuddin Râzî, Muhâkemâtü Șerhayi'l-İşârât, 399.

${ }^{61}$ Kutbuddin Râzî, Muhâkemâtü Șerhayi'l-İşârât, 339.

${ }^{62}$ Kutbuddin Râzî, Muhâkemâtü Şerhayi'l-İşârât, 399.
} 
dir, hemen olur (kün feyekûn)" sözü doğrular"63 demiştir. Varlığın O'nun bilgisine tabi olması sadece bilmesi değil aynı zamanda yaratması anlamındadır. Cüz'îler dâhil her şeyin Allah'ın bilgisine tabi olması O'nun en küçük zerresine kadar cüz'îleri yarattığı anlamına gelir. İbn Sînâ'nın Kaderin Sırrı Risalesi'nde yer alan sözleri de bu düşünceyi destekler niteliktedir. Risale'de şöyle demiştir: "Ulvî ya da süflî cüzleriyle birlikte bütün âlemde, varlığı ve ortaya çıkışının sebebi Allah Teâla olmaksızın, Allah'ın bilgisi, idaresi ve o şekilde olmasını dilemesi dışında var olan hiçbir şey bulunmadığını bilmektir."64 İbn Sînâ'nın diğer eserlerindeki sözleri Risa$l e$ 'deki sözleriyle birikte değerlendirildiğinde sonuç olarak Allah'ın eşyayı eşya ortaya çımadan önce bildiği, bu bilginin sebebinin kendi Zat'ı olduğu ve dolayısıyla da eşyanın varlığının bu bilgiye göre zorunlu olarak ortaya çıktığı anlaşılmaktadır. Bunu İbn Sînâ'nın sözleriyle beyan edecek olursak “her şey sebebiyle ve O'na izafetle zorunludur. Dolayısıyla 0'na izafetle bilfiil olarak mevcuttur". ${ }^{65}$ Buna göre İbn Sînâ'nın kaderci bir yaklaşıma sahip olduğunu söyleme imkânımız doğmaktadır.

Fahreddin Râzî kullara ait fiilerin meydana gelişiyle ilgili görüşleri aktarırken tercih ettiği görüşü şöyle açıklamıștır: "Kudret ve sebep bir araya geldikten sonra fiilin ortaya çıkması vaciptir. Çünkü kadir fiili yapabilen veya terk edebilendir. $\mathrm{Bu}$ eşitlik beraberinde iki taraftan birinin tercihini imkânsız hale getirir. $\mathrm{Bu}$ durumda sebebin dâhil olmasıyla hangi tarafinda var olacağı belirlenir. Böylece fiilin vukuu vacip olur". ${ }^{66} \mathrm{Bu}$ görüş Râzî’nin söylediği gibi filozofların da görüşüdür;fiilin varlığı kudret ve sebebin valığına bağlıdır. Fakat filozoflarla bir nokta ayrıştıklarını belirtmiştir. Râzî fiilin meydana gelmesi için kudret ve sebebin yeterli olup olmadığı sorusunu sormuştur. Filozoflara göre bunlar yeterli değildir. Kudret ve sebep bir araya gelince tam istidat olușur. Bundan sonra varlık vâhibu'ssuverden taşar ve amhiyetler varlığa çıkarlar. ${ }^{67}$ Râzî̀nin anlatımına göre filozoflar kula ait fiillerin var olmasını kulun dışında birine bağlamaktadır. Vâhibu's-suver'in varlık vermesi fiilin ortaya çıkması için zorunludur. Nitekim İbnü'l-Melâhimî onları bu konuda cebri tercih ettikleri için eleştirmiştir. Ona göre İbn Sînâ kula ait fiilin harici bir sebeple (vâhibu's-suver) vacip olduğunu söylemiştir. Bu da onun kaderci cebrî olduğunu göstermektedir. ${ }^{68}$ Determinizmle şekillenen İbn Sîna'nın insan fiilleri anlayışı çerçevesinde insanın özgürlüğü için yer yoktur. ${ }^{69}$

İbn Sînâ'nın kader görüşünü bize göre en açık şekilde yansitan sözleri Ta'lîkât'ta yer alan ve Vâcibu'l-vücûd'la diğer varlıkların kudret ve ihtiyarının farkına dair söyledikleridir. Ona göre insan bilkuvve muhtardır ve bir müreccihe ihtiyacı vardır. İnsandaki bilkuvve ihtiyarın fiile çıkması için bir sebep gereklidir. $\mathrm{Bu}$

\footnotetext{
63 İbn Sînâ, et-Ta'lîkât, 116.

${ }^{64}$ George F. Hourani, “İbn Sînâ'nın Kaderin Sırrı Risalesi”, çev. Aydın Özdemir, Marife Dini Araştırmalar Dergisi 13/3 (Ocak 2013), 172.

65 İbn Sînâ, et-Ta'lîkât, 29.

${ }^{66}$ Fahreddin Râzî, el-Metâlib, 9/ 11.

${ }^{67}$ Fahreddin Râzî, el-Metâlib, 11.

${ }^{68}$ Rüknüddîn Mahmûd b. Muhammed İbnü'l-Melâhimî, Tuhfetü'l-mütekellimîn fi'r-red ale'l-felâsife, thk. Hasan Ensârî (Tahran: Müessest-i Pezvehşî Hikmet ve Felefe-i İran, 1387), 144; Orhan Şener Koloğlu, Mutezile'nin Felsefe Eleştirisi (Bursa: Emin yayınları, 2010), 288.

${ }^{69}$ Koloğlu, Mutezile'nin Felsefe Eleştirisi, 291.
} 
durumda muhtar olan insan aslında muztar hükmündedir. ${ }^{70}$ İbn Sînâ Vâcibu'lvücûd'la insanın ihtiyarını karşılaștırdığı bu cümlelerinde insanın ihtiyarını sebebe bağlamış ve bu sebebi zincir olarak Vâcibu'l-vücûd'a kadar devam ettirmiștir. Nitekim ona göre "insan muhtar suretinde muztardır" ifadesinin manası bizden ihtiyar sahibi olanları seçtiği fiile yönlendiren bir sebebin bulunmasıdır. ${ }^{71} \mathrm{Bu}$ da demek oluyor ki insan muhtar olduğu halde kendisini yaptığı fiili yapmaya zorunlu kılan bir sebebe bağlı olarak hareket etmektedir. Bu harekette tabiî hareket gibi icbar altındadır. Çünkü bir amaç ve sebebe bağlı olarak ortaya çıkmaktadır. ${ }^{72} 0$ sebep de başka bir sebebe bağlıdır ve bu sebep zinciri ilk sebep olan Vâcibu'l-vücûd'da son bulmaktadır. Vâcibu'l-vücûd da aynı sebepler zinciriyle insanın her halini bilmektedir. Dolayısıyla İbn Sînâ'nın söylediği gibi varlığın var olması Vâcibu'l-vücûd'un onları bilmesine bağlıdır. O’nun bilgisi varlığı zorunlu kılmaktadır. Vâcibu'lvücûd'un indinde imkândan söz edilemez. Çünkü imkân Vâcibu'l-vücûd için tereddüt demektir. O’nun tereddütte olması imkânsızdır. Bu sebeple mümkün varlık kategorisi içinde yer alan insan ve fiillerinin Vâcibu'l-vücûd indinde zorunlu olduğu aşikârdır.

İbn Sînâ'nın kaderle ilgili görüşünü yansıtan diğer ifadeleri Ta'lîkât'takiler kadar net olmasa da Isşârât'ta "Kader varsa ceza neden var?" sorusuna verdiği cevaptadır. ${ }^{73}$ Öncelikle belirtelim ki Fahreddin Râzî bu sorunun kendi içinde çelişkili olduğunu söylemiştir. Çünkü ona göre kaderi kabul ettikten sonra cezanın da kaderin içinde olması gerekmektedir. Dolayısıyla kaderden ayrı düşünülmeyen cezanın varlığının sorgulanması tutarlı değildir. ${ }^{74}$ Fahreddin Râzî böylece İbn Sînâ'nın kaderi kabul ettiğini ve buna göre de cezanın varlığını sorgulamasının anlamsız olduğunu söylemek istemektedir. İbn Sînâ'nın kendi sorduğu soruya verdiği cevaba dönecek olursak; o, bu soruyu bir benzetme ile cevaplamaktadır: Nefsin hatalarından dolayı ceza görmesi, obur insanın oburluğundan dolayı hasta olması gibi zorunlu bir sonuçtur. ${ }^{75}$ İbn Sînâ burada kişinin dünyadaki yanlış seçimlerinin zorunlu sonucu olarak cezaya çarptırıldığını söylemektedir. Ona göre nefs bedenden ayrıldıktan sonra zaruri olarak bu ceza tahakkuk edecektir. ${ }^{76}$

Cezanın tahakkukunu İşârât' ta kulun seçimlerine bağlayan İbn Sînâ bir önceki paragrafta da görüldüğü üzere bu seçimlerin sebebini zincirleme olarak Vâcibu'l-vücûd'a kadar götürmekte ve netice itibariyle hepsinin kendi sebebinin zorunlu sonucu olduğunu söylemektedir. Ona göre ceza nefsin yapıp ettiklerinin zorunlu sonucu olduğu gibi nefsin yapıp ettikleri de kendi sebeplerinin zorunlu sonuçlarıdır. Ancak İbn Sînâ cezanın nefsin kazanımlarının zorunlu sonucu olduğunu söylemesine rağmen nefsin kazanımlarının sebebine dair açıklamalarını burada yapmamakta bu meseleye dair olası soruları "bunların harici sebebiyle ilgili

\footnotetext{
70 İbn Sînâ, et-Ta'lîkât, 50.

71 İbn Sînâ, et-Ta'lîkât, 51.

72 İbn Sînâ, et-Ta'lîkât, 53.

73 İbn Sînâ, el-İşârât, 311.

${ }^{74}$ Muhammed b. Ömer b. Hüseyn Fahreddin Râzî, Şerhu'l-İşârât ve't-tenbîhât, thk. Ali Rıza Necefzâde (Tahran: Müesseset-i çâp ve intişârât-ı Dânişnâ-i Tahran, 1386), 562.

75 İbn Sînâ, el-İşârât, 311.

${ }^{76}$ Fahreddin Râzî, Şerhu'l-İşârât ve't-tenbîhât, 561.
} 
durum başka bir konudur"77 diyerek adeta geçiştirmektedir. Kutbuddin Râzî Eş'arîlerin tek illet olarak Allah Teâlâ'yı gördüklerini, filozofların ise kaderde ilk illete kadar silsile halinde illetlere sahip olduğunu söylemektedir. ${ }^{78}$ Malulün, tam illetinden zorunlu olarak sadır olduğu düşüncesine göre filozofların illeti zatî illet ve hazırlayıcı illet olarak tasnif ettiğini de göz önünde tutarak eğer Allah tam illetse başka hiçbir illete ihtiyaç kalmadan malulün O'ndan sadır olması gerekmektedir. Yok, eğer hazırlayıcı illetse bu durumda gerçek bir zatî illet olmadığı için malulü bilmesi zorunlu değildir. Şöyle ki bir inşaat yapmak isteyen müteahhit malzemeleri alıp, ustayı da bulduktan sonra o binanın zatî illeti binayı yapan usta mıdır yoksa müteahhit midir? Cevap müteahhit olduğu zaman durum Eş'arîlerin söylediği gibidir yani tek illet vardır o da Allah'tır çünkü binayı yapan usta olsa da binanın ortaya çıkmasının nedeni müteahhittir. Cevap usta olursa bu durumda müteahhit ancak hazırlayıcı neden olur ve binanın olduğu yere gitmediği takdirde binaya dair bilgisi olmaz.

İbn Sînâ'nın Allah'ın cüz'îleri bilmesi dair yaptığı açıklama yani O'nun cüz'îleri küllî olarak ve bir defada biliyor olması Ehl-i sünnetin Allah'ın her şeyi ezeli olarak, tek bir bilgiyle, bilgisinde değișim olmadan bildiği şeklindeki görüşüne paralel anlaşılmalıdır. Aksi halde sebebi bilmenin malulü zorunlu olarak bilmeyi gerektirir açıklaması, Gazzâlî̀nin haklı olarak eleştirdiği gibi, Allah'ın cüz'îleri bilmediği sonucuna varmaktadır. Kutbuddin Râzî bu durumu açıç̧a ifade etmese de eserinde yer alan cümleleri bizi bu şekilde düşünmeye sevk etmektedir.

\section{Sonuç}

Gazzâlî'nin yaptığı eleștirilersonucundaİbn Sînâ'nın Allah’ın cüz'îleri küllî olarak bildiğine dair görüşü tartışmaya açılmıştır. Âlimler, Gazzâlî gibi bu görüşün Allah'ın cüz'îleri bilmediği sonucuna çıktığını iddia edenler ve İbn Sînâ'nın görüşünü savunanlar olarak ikiye bölünmüștür. İbn Sînâ'yı savunanlardan bir kısmı savunusunu onun İşârât isimli eserini şerh ederken yapmışlardır. Bunlardan birisi de Kutbuddin Râzî'dir. Kutbuddin Râzî İbn Sînâ'nın Allah'ın cüz'îleri bildiğini kabul etmekle birlikte onun ortaya koyduğu görüşün izahının diğer Isşârât şarihi Nasîruddin Tûsî̀nin yaptığı gibi yapılamayacağını söylemiştir. Bunun yanında izahın nasıl yapılması gerektiğine dair sorulacak olan bir soruya yanıtı çok net değildir. Fakat eserinde yer alan bir pasajda Allah'ın eșyayı ezelden ebede hazır olarak bildiğini söylemektedir. Onun bu sözleri İbn Sînâ'nın farklı eserlerinde yer alan sözleriyle karşılaştırıldığında ve bütüncül bir okuma yapıldığında İbn Sînâ'nın Allah'ın cüz'îleri nasıl bildiğine dair görüşünün izahının kaderci tutumla paralel gittiği görülecektir.

İbn Sînâ'nın Allah'ın eșyanın ilkesi olan Zat'ına dair bilgisinin neticesinde eşyanın zorunlu olarak meydana geldiği düşüncesi ve çeşitli eserlerinde kadere ve inşaların fiillerine dair görüşü onun Allah'ın eşyaya dair bilgisinin eşya var olmadan önce ezeli olarak Zat'ında bulunduğu sonucunu doğurmaktadır. Ehl-i sünnetin

\footnotetext{
77 İbn Sînâ, el-İşârât, 311.

${ }^{78}$ Kutbuddin Râzî, Muhâkemâtü Şerhayi'l-İşârât, 414.
} 
Allah'ın her şeyi ezeli olarak tek bir bilgi ile Zat'ında değişim olmadan bildiği şeklindeki görüşü İbn Sînâ'nın Allah'ın cüz’̂̂leri küllî olarak bildiğine dair görüşünün olması gereken izahı gibi görünmektedir. Nitekim İbn Sînâ'nın cüz'îlerin ancak illetleriyle akledilebileceği fikri onu ya Gazzâlînnin iddia ettiği gibi cüz'îlerin akledilemeyeceği sonucuna ya da kaderci anlayıșa sevk edecektir. İbn Sînâ'nın illet-malul ilişkisine dair fikirleri de Allah'ın eșyanın hepsini var olmadan önce ezelde bilmesini gerektirmektedir. Çünkü O’nun Zat'ı eşyanın illetidir ve 0 zatî illettir. Zatî illetten malulün suduru zorunludur, ertelenemez. Dolayısıyla eșya O'ndan sadır olduğuna göre eşyanın hepsini bilmektedir. Aradaki illetler İbn Sînâ'nın Allah'tan çokluğu nefyetmek için başvurduğu fakat başarısız olan bir yöntemin getirdiği sonuçtur.

Funding / Finansman: This research received no external funding. / Bu araștırma herhangi bir diş fon almamıştır.

Conflicts of Interest / Çıkar Çatışması: The author declare no conflict of interest. / Yazar, herhangi bir çıkar çatışması olmadığını beyan eder.

\section{Kaynakça}

Acar, Rahim. "Allah'ın Cüz'̂̂leri Bilmesi: Klasik İbn Sînâ Yorumunun Değerlendirilmesi". Divan: Disiplinlerarası Çalışmalar Dergisi 20 (Haziran 2006), 99-118.

Acar, Rahim. "Yaratan Bilmezse Kim Bilir? İbn Sînâ'ya Göre Allah'ın Cüz'îleri Bilmesi”. İslam Araştırmaları Dergisi 13 (2005), 1-23.

Aydın, İbrahim Hakkı. "Tehâfüt Geleneği Üzerine Bir Değerlendirme". Atatürk Üniversitesi Ilahiyat Fakültesi Dergisi 26 (Aralık 2006), 57-74.

Fahreddin Râzî, Muhammed b. Ömer b. Hüseyn. el-Metâlibu'l-âliyye mine'l-ilmi'l-ilâhiyye. thk. Ahmed Hicâzî es-Sefâ. Beyrut: Dâru'l-kitâbi'l-Arabî, 1987.

Fahreddin Râzî, Muhammed b. Ömer b. Hüseyn. Serhu'l-İşârât ve't-tenbîhât. thk. Ali Rıza Necefzâde. Tahran: Müesseset-i çâp ve intișârât-ı Dânișnâ-i Tahran, 1386.

Gazzâlî, Ebû Hamîd Muhammed b. Muhammed. Faysalü't-tefrika. çev. Hikmet Akpur. İstanbul: İlk Harf Yayınevi, 2015.

Gazzâlî, Ebû Hâmid Muhammed b. Muhammed b. Muhammed b. Ahmed. "el-Munkızu mine'd-dalâl". Mecmû'atü resâili'l-Imâmi'l-Gazzâlî. ed. Ahmed Şemseddin. Beyrut: Dâru'l-kütübi'l-ilmiyye, 1988.

Gazzâlî, Ebû Hâmid Muhammed b. Muhammed b. Muhammed b. Ahmed. Filozofların Tutarsızlı̆ğ. çev. Mahmut Kaya. İstanbul: TÜYEK, 2014.

Gazzâlî, Ebû Hâmid Muhammed b. Muhammed b. Muhammed b. Ahmed. Tehâfütü'l-felâsife. thk. Ahmed Şemseddin. Beyrut: Dâru'l-kütübi'l-ilmiyye, 2010.

Hocazâde, Muslihuddin Mustafa b. Yûsuf. et-Tehâfüt fi'l-muhâkemeti beyne'l-Gazzâlî ve'lfelâsife. thk. Luay Hatem Yaqoob. Beyrut: Dâru'r-risâleti'l-âlemiyye, 2018.

Hourani, George F. "İbn Sînâ'nın Kaderin Sırrı Risalesi”. çev. Aydın Özdemir. Marife Dini Araştırmalar Dergisi 13/3 (Ocak 2013), 169-189.

Ilgaroğlu, Muhammet Caner - Yaqoob, Luay Hatem. "Allah'ın Cüz'îleri (Tikeller) Bilmesi Meselesi: İbn Sinâ, Gazzâlî ve Hocazâde'nin Görüșlerinin Karşılaștırılması". MANAS Sosyal Araştırmalar Dergisi 8/1 (Şubat 2019), 940-950.

İbn Rüşd, Muhammed b. Ahmed b. Muhammed el-Kurtubî. Felsefe-Din İlişkileri. çev. Süleyman Uludağ. İstanbul: Dergah Yayınları, 2016.

İbn Rüşd, Muhammed b. Ahmed b. Muhammed el-Kurtubî. Tehâfütü't-Tehâfüt. Beyrut: Dâru'l-kütübi'l-ilmiyye, 2014.

İbn Sehlân, Kâdî Zeynüddîn Ömer b. Sehlân es-Sâvî, Hasan el-Merâĝi. Nehcü't-takdîs. Tahran: 
Şems-i Tebrîzî, 2006.

İbn Sînâ, Ebû Alî el-Hüseyn b. Abdillâh b. Alî. el-İşârât ve't-tenbîhât -Illâhiyyât-. thk. Süleyman Dünya. Beyrut: Müessesetü'n-Nu'mân, 1993.

İbn Sînâ, Ebû Alî el-Hüseyn b. Abdillâh b. Alî. er-Risâletü'l-arşiyye. thk. İbrahim Hilâl. Mısır: y.y., ts.

İbn Sînâ, Ebû Alî el-Hüseyn b. Abdillâh b. Alî. eş-Şifâ -Illâhiyyat-. Kum: Mektebetü semâhat, 2012.

İbn Sînâ, Ebû Alî el-Hüseyn b. Abdillâh b. Alî. et-Ta'lîkât. Kum: Mektebetü'l-ilâmi'l-İslâmî, 1404.

İbn Sînâ, Ebû Alî el-Hüseyn b. Abdillâh b. Alî. Kitâbü'n-necât. Tahran: İntişârât-ı dânişnâ, ts.

İbnü'l-Melâhimî, Rüknüddîn Mahmûd b. Muhammed. Tuhfetü'l-mütekellimîn fi'r-red ale'lfelâsife. thk. Hasan Ensârî. Tahran: Müessest-i Pezvehşî Hikmet ve Felefe-i İran, 1387.

Karabâĝî, Muhyiddîn Muhammed b. Alî. Ta'lika alâ şerhi Tehâfüti'l-felâsife li Hocazâde. çev. Abdurrahim Güzel. Ankara: Kültür ve Turizm Bakanlığı Yayınları, 1991.

Kemalpaşazâde, Şemseddin Ahmed. Hâşiye alâ Tehâfütü'l-felâsife. çev. Ahmet Arslan. Ankara: Kültür ve Turizm Bakanlığı Yayınları, 1987.

Koloğlu, Orhan Şener. Mutezile’nin Felsefe Eleștirisi. Bursa: Emin yayınları, 2010.

Kutbuddin Râzî, Ebû Abdillâh Muhammed b. Muhammed. el-îlâhiyyât mine'l-muhâkemâti beyne Şerhayi'l-Isşârât. thk. Hâdîzâde Mecîd. Tahran: Merkez-i neşr-i miras-ı mektûb, 1381.

Nasîruddin Tûsî, Muhammed b. Muhammed b. el-Hasen. el-Isşârât ve't-tenbîhât me'a şerhi Nasîruddin et-Tûsî. thk. Süleyman Dünya. Beyrut: Müessesetü'n-Nu'mân, 1993.

Nîsâbûrî, Fahreddin Muhammed b. Ali el-İsferâyînî. Şerhu Kitâbü’n-necât. Tahran: İncemin âsâr ve mefâhir-i ferhengî, 1383.

Terkan, Fehrullah. “İbn Sînâ, Zorunlu Varlık'ın Cüz'iyyâtı Bildiğini Tutarlı Olarak İddia Edebilir mi?" Uluslararası İbn Sînâ Sempozyumu. ed. Mehmet Mazak. 345-356. İstanbul: İstanbul Kültür A.Ș. Yayınları, 2009. 